\title{
Biomarker records of palaeoenvironmental variations in subtropical Southern Africa since the late Pleistocene: Evidences from a coastal peatland
}

\author{
Andrea Baker, Joyanto Routh and Alakendra N Roychoudhury
}

\section{Linköping University Post Print}

\section{Tweet}

N.B.: When citing this work, cite the original article.

Original Publication:

Andrea Baker, Joyanto Routh and Alakendra N Roychoudhury, Biomarker records of palaeoenvironmental variations in subtropical Southern Africa since the late Pleistocene: Evidences from a coastal peatland, 2016, Palaeogeography, Palaeoclimatology, Palaeoecology, (451), 1, 1-12.

http://dx.doi.org/10.1016/j.palaeo.2016.03.011

Copyright: Elsevier

http://www.elsevier.com/

Postprint available at: Linköping University Electronic Press

http://urn.kb.se/resolve?urn=urn:nbn:se:liu:diva-128806

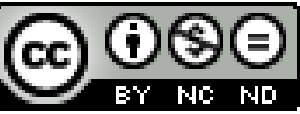




\title{
BIOMARKER RECORDS OF PALAEOENVIRONMENTAL VARIATIONS IN SUBTROPICAL SOUTHERN AFRICA SINCE THE LATE PLEISTOCENE: EVIDENCES FROM A COASTAL PEATLAND
}

\author{
Andrea BAKER ${ }^{1}$, Joyanto ROUTH ${ }^{2 *}$, Alakendra N. ROYCHOUDHURY ${ }^{1}$ \\ ${ }^{1}$ Department of Earth Sciences, Stellenbosch University, Stellenbosch, South Africa \\ ${ }^{2}$ Department of Thematic Studies - Environmental Change, Linköping University, 58183, Linköping, \\ Sweden
}

\begin{abstract}
Southern Africa's unique global position has given rise to a dynamic climate influenced by large sea surface temperature gradients and seasonal fluctuations in the Inter Tropical Convergence Zone. Due to the semi-arid climate of the region, terrestrial palaeorecords are rare and our understanding of the long-term sensitivity of Southern African terrestrial ecosystems to climatic drivers is ambiguous. A $810 \mathrm{~cm}$ continuous peat core was extracted from the Mfabeni peatland with ${ }^{14} \mathrm{C}$ basal age of c. 47 thousand years calibrated before present (kcal yr BP), positioning it as one of the oldest known sub-tropical coastal peatlands in Southern Africa. This peat core provides an opportunity to investigate palaeoenvironmental changes in subtropical Southern Africa since the late Pleistocene. Biomarker ( $n$-alkane, $n$-alkanoic acid and $n$-alkanol) analysis, in conjunction with previously published bulk geochemical data, was employed to reconstruct organic matter (OM) sources, rates of OM remineralisation and peatland hydrology. Our results showed that the principal OM source into the peatland was emergent and terrestrial plants with exception of shallow lake conditions when submerged macrophytes dominated (c. 44.5-42.6, 29.7, $26.1-23.1,16.7-7.1$ and $2.2 \mathrm{kcal}$ yr BP). $n$-Alkane proxies suggest that local plant assemblages were predominantly influenced by peatland hydrology. By incorporating temperature sensitive $n$-alkanoic acid and $n$ alkanol proxies, it was possible to disentangle the local temperature and precipitation changes. We report large variations in precipitation intensities, but subdued temperature fluctuations during the late Pleistocene. The Holocene period was characterised by overall elevated temperatures and precipitation compared to the preceding glacial period, interspersed with a millennial scale cooling event. A close link between the Mfabeni archive and adjacent Indian Ocean marine core records
\end{abstract}


was observed, suggesting the regional ocean surface temperatures to be the dominant climate driver in this region since the late Pleistocene.

Keywords: Southern Africa; Biomarkers; Late Pleistocene; Holocene; Palaeoenvironment; Subtropical peatland.

* Corresponding author: Joyanto Routh, Department of Thematic Studies - Environmental Change, Linköping University, 58183, Linköping, Sweden. Email: jovanto.routh@liu.se. Tel: +46704931066

\section{Introduction}

Southern Africa is situated at a dynamic junction between tropical, sub-tropical and temperate climate systems. The region is dominated by large seasonal fluctuations in the Inter Tropical Convergence Zone (ITCZ; Stokes et al., 1997) and high sea surface temperature (SST) gradients between the warm Agulhas and cold Benguela oceanic currents fringing the region (Preston-Whyte and Tyson, 1998; Tyson and Preston-Whyte, 2000). Uncertainty, however, still surrounds the interactions between these different climate drivers, and whether terrestrial ecosystems in the region responded abruptly or gradually to the ensuing climatic shifts, most notably during the transition from the last glacial maximum (LGM) to the Holocene. The biggest hindrance to understanding the Southern African palaeoclimate (and the environmental responses to climate fluctuations) is the general lack of continuous terrestrial archives (Nash and Meadows, 2012; Scott et al., 2008), mainly due to the region's topography and a semi-arid climate not being conducive for the preservation of sedimentary climate archives (Chase and Meadows, 2007).

Regional terrestrial archives in Southern Africa that have been explored vary from speleothems (Holmgren et al., 2003; Holzkämper et al., 2009; Lee-Thorp et al., 2001; Talma and Vogel, 1992), coastal or inland lake sediments (Kristen et al., 2010; Meadows et al., 1996; Neumann et al., 2008, 2010; Partridge, 2002; Walther and Neumann, 2011) and regional peatlands (Baker et al., 2014; Finch and Hill, 2008; Grundling et al., 2013; Norström et al., 2009) to hyrax midden deposits (Chase 
et al., 2012, 2011, 2010; Valsecchi et al., 2013) and multi-archive studies (Chase and Meadows, 2007; Chase and Thomas, 2007; Meadows, 2001; Meadows and Baxter, 1999; Scott et al., 2008).

Nonetheless, these archives record site specific palaeoenvironmental conditions over varying time intervals, and only a few extending as far back as the LGM. In addition, many records are temporally discontinuous, suffer from dating uncertainties and tend to be geographically clustered resulting in lack of ubiquitous distribution of archives across the region. In addition, conclusions derived from different proxies often yield different results and magnitudes in response to the perceived climate variability in the region. Therefore, additional high resolution multi-proxy and multi-archive studies are required to elucidate terrestrial environmental responses to past climatic shifts in Southern Africa.

Peat deposits are ideally suited for palaeoclimate research. Their high degree of preservation and predominantly climate regulated autochthonous depositional regimes (Strack et al., 2008); make them suitable for reconstructing environmental responses to climate fluctuations. Although some studies have been done on peatlands in the (sub)tropics (Anderson and Muller, 1975; Dommain et al., 2014, 2011; Kurnianto et al., 2014; Norström et al., 2009; Page et al., 2011; Staub and Esterle, 1994), the majority of peatland research undertaken has mainly focused on northern Hemisphere boreal/temperate peatlands. Hence, limited scientific understanding exists of the processes that regulate carbon (C) cycling in sub-tropical and tropical peatlands (Chimner and Ewel, 2005), and how peatland C flux responds to climate change. The Mfabeni peatland core has a basal ${ }^{14} \mathrm{C}$ age of c. 47 thousand years calibrated before present ( $\mathrm{kcal}$ yr BP; $805 \mathrm{~cm}$ ), positioning it as one of the oldest continuous coastal peatland records in Southern Africa (Baker et al., 2014; Finch and Hill, 2008; Grundling et al., 2013). The peatland owes its longevity to the protection against sea level fluctuation, and enhanced groundwater transmissivity (Grundling et al., 2013) of the c. 100m high coastal dune corridor (c. $55 \mathrm{kcal}$ yrs BP; Porat and Botha; 2008). This unique archive offers us an opportunity to explore, in high resolution, environmental responses to palaeoclimatic fluctuations in Southern Africa since the late Pleistocene. 
Of special interest for palaeoclimate researchers are the records of molecular proxies preserved in geological archives. Biomarker proxies have been widely used by researchers to delineate organic matter (OM) sources, moisture availability, preservation and ambient temperatures in boreal / temperate peatlands and lakes (Andersson et al., 2012, 2011; Bai et al., 2009; Ficken et al., 1998; Ishiwatari et al., 2005; Nichols et al., 2006; Ogura et al., 1990; Rieley et al., 1991; Routh et al., 2014; Wang et al., 2012; Xie et al., 2004; Zheng et al., 2011a, 2007; Zhou et al., 2010); sub-tropical lakes, estuaries and wetlands (Al-Mutlaq et al., 2008; Ficken and Farrimond, 1995; Huang et al., 1999; Jaffé et al., 2001; Mead et al., 2005; Ranjan et al., 2015; Zhou et al., 2005); marine sediments (Hu et al., 2002; Pancost and Boot, 2004), aerosols (Bendle et al., 2007, 2006; Schefuß et al., 2003) and semiarid soils (Carr et al., 2014). While these biomarker palaeoproxies are established tools for elucidating palaeoenvironments (Meyers 2003), they each individually suffer from unique limitations, and therefore should be interpreted with caution and always employed within a multiproxy approach to mitigate their inadequacies.

The aim of our study is to explore the late Pleistocene and Holocene environment and to reconstruct the climatic controls governing the Mfabeni peatland in southern Africa (Figure 1). We employ a combination of established biomarker ratios as part of a multi-proxy study to reconstruct fluctuations in OM sources, palaeohydrology and microbial reworking. These reconstructions are then used to infer climatic conditions that could have driven these environmental changes. We substantiate our findings by comparing the Mfabeni archive with other regional climate records.

\section{Methods}

\subsection{Site description}

The UNESCO world Heritage iSimangaliso Wetland Park is situated on the northern shores of Kwazulu-Natal province, South Africa (Figure 1). Within the park, the shallow $350 \mathrm{~km}^{2}$ St Lucia Lake forms part of the largest estuarine wetland system on the African continent (Vrdoljak and Hart, 2007). On the eastern shores of Lake St Lucia, the Mfabeni fen lies within an interdunal valley 
(Botha and Porat, 2007) measuring c. $10 \times 3$ km (Clulow et al., 2012; Grundling et al., 2013), and up to $11 \mathrm{~m}$ deep (Grundling et al., 2013; Grundling, 2001). The fen's hydrology is influenced primarily by circum-neutral $\mathrm{Ca}^{2+}$ and $\mathrm{HCO}^{3-}$ dominated groundwater of the Maputaland aquifer, that is structurally controlled by the north-south aligned coastal dune corridor (Grundling et al., 2013; Taylor et al., 2006a; Venter, 2003), and local precipitation. The region has a sub-tropical climate and experiences mainly austral summer rainfall of between 900 and 1200 mm/yr (Grundling, 2001; Taylor et al., 2006b). However, distinct cyclical dry-wet periods have been identified in the contemporary rainfall records from this region (Bate and Taylor, 2008). The Mfabeni fen forms part of the greater Natal Mire Complex (NMC; Figure 1) that extends from southern Mozambique to the south of Richards Bay, Kwazulu-Natal, and was formed by valley infilling within the KwaMbonanbi formation coastal dune depression (Smuts, 1992). The iSimangaliso wetland park vegetation is made up of Maputaland wooded grassland, coastal belt and sub-tropical freshwater wetland and northern coastal forests (Mucina et al., 2006), whereas the fen itself is dominated by herbaceous reed sedges and grasses (Finch, 2005).

\subsection{Sampling techniques}

Core SL6 was extracted from the middle of the Mfabeni fen $\left(28.15021^{\circ} \mathrm{S} ; 32.52508^{\circ} \mathrm{E}\right)$ to a depth of $810 \mathrm{~cm}$ in consecutive drives, using a Russian peat corer consisting of a $5 \mathrm{~cm}$ diameter and $50 \mathrm{~cm}$ long core chamber. The individual cores were catalogued in the field, photographed and later described and sectioned into $1-2 \mathrm{~cm}$ intervals in the laboratory, after which the sediments were freeze-dried in preparation for various analysis.

\subsection{Radiocarbon dating / age model}

${ }^{14} \mathrm{C}$ radiocarbon dating and age-depth modelling was done as per methods listed in Baker et al. (2014) and references therein. Nine selected raw peat samples (at 10, 109, 209, 309, 405, 510, 609, 709 and $805 \mathrm{~cm}$ ), rootlets removed and pre-treated with $0.25 \mathrm{M} \mathrm{HCl}$, were measured on a Compact Carbon AMS and conventional ${ }^{14} \mathrm{C}$ ages were calculated using a correction factor for isotopic 
fractionation (supplementary data Table A1). These ages were then calibrated using the northern hemisphere terrestrial calibration curve IntCal09 with a $40 \pm 20{ }^{14} \mathrm{C}$ year southern hemisphere offset (supplementary data Figure S1). Ages were then adjusted using the age-depth Bacon modelling software (Blaauw and Christeny, 2011).

\subsection{Lipid extraction}

A modified lipid extraction was undertaken as per the protocol set out by Wakeham et al. (2002) on 36 selected peat samples spanning the length of core SL6 and analysed for $n$-alkane, $n$-alkanoic acid and $n$-alkanol concentrations. The geochemical analyses were measured on the same intervals (including the nine ${ }^{14} \mathrm{C}$ radiocarbon dated samples). Approximately $2 \mathrm{~g}$ of freeze-dried sediment, including recovery standard (deuterated hexatriacontane), was extracted with a mixture of $\mathrm{CH}_{2} \mathrm{Cl}_{2}$ and $\mathrm{CH}_{3} \mathrm{OH}(9: 1 \mathrm{v} / \mathrm{v})$ on a Dionex automated solvent extractor for two successive cycles (1000 psi at $75^{\circ} \mathrm{C}$ and $140^{\circ} \mathrm{C}$, respectively). An aliquot of the extracted total lipid extract (TLE) was saponified with $0.5 \mathrm{~N} \mathrm{KOH}$ (in methanol) at $100^{\circ} \mathrm{C}$ for 2 hours. After cooling, $5 \% \mathrm{NaCl}$ was added to the TLE, agitated and then washed with successive aliquots of hexane to separate the neutral (TLE-N) and acidic (TLE-A) fractions. The TLE-N fraction was then introduced into a long glass column packed with deactivated 60 mesh silica gel. The $n$-alkane (F1) fraction was first eluted by passing $10 \mathrm{~mL}$ of hexane and then $5 \mathrm{~mL}$ of $25 \%$ toluene: $75 \%$ hexane solution. The $n$-alkanol (F2) fraction was eluted by sequentially introducing $5 \mathrm{~mL}$ aliquots of increasing percentages of ethyl acetate in hexane $(5 \%$ ethyl acetate: $95 \%$ hexane; $10 \%$ ethyl acetate: $90 \%$ hexane; $15 \%$ ethyl acetate: $85 \%$ hexane and $20 \%$ ethyl acetate: $80 \%$ hexane). The condensed F2 extract was then derivitized with BSTFA and pyridine at $70^{\circ} \mathrm{C}$ for 2 hours. The TLE-A fraction was acidified with $6 \mathrm{~N} \mathrm{HCl}$, extracted with hexane and derivitized with $10 \% \mathrm{BF}_{3}$ (in methanol) for 2 hours at $100^{\circ} \mathrm{C}$. All extracts were spiked with internal deuterated-tetracosane and androstane standards. The samples were then injected in splitless mode into an Agilent $6890 \mathrm{~N}$ gas chromatography (GC) interfaced to a 5973 MSD mass-spectrometer (MS) with a DB-5 (5\%phenyl, 95\% dimethyl polysiloxane) fused silica capillary column (30 m length $\mathrm{x}$ 
$0.25 \mathrm{~mm}$ i.d. $\times 0.25 \mu \mathrm{m}$ film thickness).

The GC oven was started at $35^{\circ} \mathrm{C}$ held isothermally for $1 \mathrm{~min}$, and increased to $130{ }^{\circ} \mathrm{C}$ at $20^{\circ} \mathrm{C} \mathrm{min}^{-1}$, the temperature was further increased to $320^{\circ} \mathrm{C}$ at $6^{\circ} \mathrm{C} \mathrm{min}^{-1}$ and held isothermally for $15 \mathrm{~min}$. The MS was operated at $70 \mathrm{eV}$ under full-scan mode (m/z 50-500), with a run-time of $57.42 \mathrm{~min}$. The compounds were identified based on their retention time and fragmentation patterns using the NIST MS Library (Version 2.0) / Lipid library (2011) and S-4066 standard ( $n$-alkanes $\mathrm{C}_{14}-\mathrm{C}_{32 \text { even }}+$ Pristane/Phytane from CHIRON). Recovery of deuterated hexatriacontane added prior to initial extraction ranged from $75-85 \%$. Detection limits of the internal standards ranged from 0.1 to 1 $\mathrm{ng} / \mathrm{mg}$ and sample reproducibility was $\pm 10 \%$. Biomarker concentrations were normalised with respect to \% total organic carbon (TOC).

\subsection{Proxies}

A geochemical proxy is a chemical compound that can be used to infer a relationship between a specific physical process and a corresponding change in the chemical component as a result of an on-going process or one that happened in the past (Hillaire-Marcel and de Vernal, 2007). The most valuable proxies are those for which a single or dominant controlling factor can be identified, and for which, preserved signals are responsive to changes in the primary process. The biomarker literature has numerous examples of its applications in tracing changes in terrestrial, lacustrine and oceanographic settings (Meyers, 2003, 1997; Peters et al., 2004). Some of these diagnostic biomarker proxies which have been used to interpret the palaeoenvironmental conditions in previous studies, and also used in this study, are summarized in Table 1.

\section{Results}

\subsection{Core description}

As reported in Baker et al. (2014), core SL6 is divided up into 7 distinct peat packages (Figures 2 and 3), from the bottom up; black fine-grained amorphous peat $(810-610 \mathrm{~cm})$; dark brown fine grained peat with grey sand zones $(610-535 \mathrm{~cm})$; black fine-grained peat with grey sand zones $(535-440$ 
$\mathrm{cm})$; black fine-grained amorphous peat with decreasing sandy texture $(440-340 \mathrm{~cm})$; black finegrained amorphous peat with minimal rootlets $(340-110 \mathrm{~cm})$; black fine-grained amorphous peat with extensive rootlets $(110-61 \mathrm{~cm})$; fine grained black amorphous peat sediments with extensive rootlets transitioning to brown "fibrous" peat $(61-0 \mathrm{~cm})$.

\subsection{Biomarker $\mathrm{C}_{\max }$ and homologue distributions}

Core SL6 (supplementary data Figure S2 and Table A2) is dominated by long chain $n$-alkanes with odd-over-even predominance and carbon chain maximums $\left(C_{\max }\right)$ at $n-C_{29}$ and $n-C_{31}(38 \%$ and $24 \%$, respectively). At $470 \mathrm{~cm}$ (c. $24.5 \mathrm{kcal} \mathrm{yr} \mathrm{BP)} \mathrm{and} \mathrm{between} 335 \mathrm{~cm}$ (c. $12.7 \mathrm{kcal} \mathrm{yr} \mathrm{BP)} \mathrm{and} 273 \mathrm{~cm}$ (c. $9.2 \mathrm{kcal}$ yr BP), $C_{\max }$ occurs at either $n-C_{23}$ or $n-C_{25}$, whereas remaining parts of the core exhibit long chain $n$-alkane $C_{\max }$ values $\left(>n-C_{25}\right)$. The $n$-alkanoic acid distributions show a predominant bi-modal distribution of $\mathrm{C}_{16}$ and mid-length chain monomers $\left(\mathrm{C}_{22} / \mathrm{C}_{24}\right)$, with prevalence of even-over-odd arrangements and $\mathrm{C}_{\max }$ of $n-\mathrm{C}_{22}$ (78\%). Likewise, the $n$-alkanols also exhibit a general bi-modal distribution of mid-length and long chain monomers, but relative low even-over-odd predominance and dominant $\mathrm{C}_{\max }$ of $n-\mathrm{C}_{22}(51 \%)$.

\subsection{TOC and biomarker concentrations}

As reported in Baker et al., (2014), the bulk TOC concentration (Figure 2, supplementary data Table A2) fluctuates between a maximum of $51.9 \%$ ( $108 \mathrm{~cm}$; c. $3.4 \mathrm{kcal}$ yr BP) and minimum of $4.5 \%$ (580 cm; c. $30.6 \mathrm{kcal}$ yr BP), with no noticeable trend up core. Besides the relative high TOC values between $789 \mathrm{~cm}$ (c. $45.7 \mathrm{kcal}$ yr BP) and $730 \mathrm{~cm}$ (c. $41.1 \mathrm{kcal}$ yr BP), $690 \mathrm{~cm}$ (c. $38.0 \mathrm{kcal} \mathrm{yr} \mathrm{BP),} 450$ cm (c. $23.1 \mathrm{kcal}$ yr BP)and from 355 till $8 \mathrm{~cm}$ (c. $14.8 \mathrm{kcal}$ yr BP throughout the Holocene, with the exception of at c. $7.1 \mathrm{kcal}$ yr BP), the core exhibits low \% TOC values at $804 \mathrm{~cm}$ (c. $46.9 \mathrm{kcal}$ yr BP), $580 \mathrm{~cm}$ (c. $30.6 \mathrm{kcal} \mathrm{yr} \mathrm{BP}$ ) and between $450 \mathrm{~cm}$ (c. $23.1 \mathrm{kcal} \mathrm{yr} \mathrm{BP)} \mathrm{and} 390 \mathrm{~cm}$ (c. $18.4 \mathrm{kcal} \mathrm{yr} \mathrm{BP,}$ coinciding with the Heinrich $3(\mathrm{H} 3)$ event and conclusion of the LGM.

The $n$-alkane concentration (supplementary data Figure S3 and Table A2) fluctuates between a maximum of $40.8 \mathrm{ng} / \mathrm{mg}$ TOC ( $375 \mathrm{~cm} ; \mathrm{c} .16 .7 \mathrm{kcal} \mathrm{yr} \mathrm{BP})$ and minimum of $2.4 \mathrm{ng} / \mathrm{mg} \mathrm{TOC} \mathrm{(450} \mathrm{cm;} \mathrm{c.}$ $23.1 \mathrm{kcal}$ yr BP), trending similarly to $n$-alkanoic acid concentrations. The $n$-alkanoic acid 
concentration exhibits a maximum of 200.1 (390 cm; c. $18.4 \mathrm{kcal} y r$ BP) and minimum of $10.2 \mathrm{ng} / \mathrm{mg}$ TOC ( $355 \mathrm{~cm}$; c. $14.8 \mathrm{kcal}$ yr BP), trending similarly to the other biomarkers. The $n$-alkanol concentration shows a similar trend as $n$-alkanoic acids, with a maximum at $390 \mathrm{~cm}$ (c. $18.4 \mathrm{kcal}$ yr BP; $36.2 \mathrm{ng} / \mathrm{mg}$ TOC) and minimum at $510 \mathrm{~cm}$ (c. $27.4 \mathrm{kcal} \mathrm{yr}$ BP; $0.1 \mathrm{ng} / \mathrm{mg}$ TOC).

\section{4. $n$-Alkane ratios}

Core SL6 profile exhibits carbon preference index ( $\mathrm{CPI}_{\text {alk}}$; Figure 2, supplementary data Table $\mathrm{A2}$ ) ranging between a minimum of $2.1(749 \mathrm{~cm} ; \mathrm{c} .42 .6 \mathrm{kcal}$ yr BP) and maximum of $12.6(92 \mathrm{~cm} ; \mathrm{c} .2 .8$ kcal yr BP), while the average chain length $\left(A C L_{\text {alk }}\right)$ values range between a minimum of 26.6 (309 cm; c. 10.4 kcal yr BP) and maximum of 30.7 ( $8 \mathrm{~cm}$; present day); both display no notable up-core trends. The aquatic plant $\left(P_{\text {aq }}\right)$ value ranges between $0.06(8 \mathrm{~cm}$; present day) and $0.66(450 \mathrm{~cm}$; $\mathrm{c}$. $23.1 \mathrm{kcal}$ yr BP), while the terrestrial leaf wax $\left(P_{\text {wax }}\right)$ proxy values range between a minimum of 0.45 $(450 \mathrm{~cm} ; \mathrm{c} .23 .1 \mathrm{kcal} \mathrm{yr} \mathrm{BP})$ and a maximum of $0.94(8 \mathrm{~cm} ; \mathrm{c.} 0 \mathrm{kcal}$ yr BP), trending opposite to the $P_{a q}$ values.

\section{5. $n$-Alkanoic acid and $n$-alkanol ratios}

The ratios between the unsaturated and saturated short chained $\left(C_{16}\right.$ and $C_{18}$; supplementary data Table A2) $n$-alkanoic acids trend towards zero within the top $76 \mathrm{~cm}$ and $157 \mathrm{~cm}$, respectively with only a few excursions to above average values for $C_{18: 1} / C_{18: 0}$ between $191 \mathrm{~cm}(c .6 .4 \mathrm{kcal}$ yr BP) and $209 \mathrm{~cm}$ (c. $7.1 \mathrm{kcal} \mathrm{yr} \mathrm{BP),} \mathrm{at} 309 \mathrm{~cm}$ (c. $10.4 \mathrm{kcal} \mathrm{yr} \mathrm{BP)} \mathrm{and} 580 \mathrm{~cm}$ (c. $30.6 \mathrm{kcal} \mathrm{yr} \mathrm{BP).} \mathrm{The} \mathrm{total}$ saturated / unsaturated $n$-alkanoic acids (sat/unsat ${ }_{\mathrm{FA}}$ ) maximises at $70.5(773 \mathrm{~cm}$; c. $44.5 \mathrm{kcal} \mathrm{yr} \mathrm{BP}$; Figure 3, supplementary data Table A1) and minimizes at $5.1(8 \mathrm{~cm} ; \mathrm{c.} 0 \mathrm{kcal}$ yr BP), trending overall negatively with the $\mathrm{C}_{16: 1} / 16: 0$ and $\mathrm{C}_{18: 1} / \mathrm{C}_{18: 0}$ ratios. The $\mathrm{CPI}$ values of the $n$-alkanoic acids $\left(\mathrm{CPI}_{\mathrm{FA}}\right.$, Figure 3, supplementary data Table A2) fluctuate predominantly at below average values $(<10)$ with the exception of between $773 \mathrm{~cm}$ (c. $44.5 \mathrm{kcal} \mathrm{yr} \mathrm{BP)} \mathrm{and} 709 \mathrm{~cm}$ (c. $39.5 \mathrm{kcal} \mathrm{yr} \mathrm{BP);} 424 \mathrm{~cm}$ (c. 23.1 kcal yr BP) and $404 \mathrm{~cm}$ (c. $19.8 \mathrm{kcal} \mathrm{yr} \mathrm{BP);} 191 \mathrm{~cm}$ (c. $6.4 \mathrm{kcal} \mathrm{yr} \mathrm{BP)} \mathrm{and} 92 \mathrm{~cm}$ (c. $2.8 \mathrm{kcal} \mathrm{yr} \mathrm{BP),} \mathrm{and}$ $41 \mathrm{~cm}$ (c. $0.9 \mathrm{kcal}$ yr BP). The $n$-alkanoic acid average chain length $\left(\mathrm{ACL}_{\mathrm{FA}}\right)$ fluctuates around the core 
average with a minimum of 23.6 (134 cm; c. $4.2 \mathrm{kcal}$ yr BP) and maximum of $25.6(355 \mathrm{~cm} ; \mathrm{c} .14 .8$ kcal yr BP).

The CPI values for $n$-alkanols ( $\mathrm{CPI}_{\text {alc }}$; Figure 3 , supplementary data Table A2) exhibit a low and narrow range of 0.25 ( $8 \mathrm{~cm}$; c. $0.0 \mathrm{kcal}$ yr BP) to $2.3(492 \mathrm{~cm}$; c. $26.1 \mathrm{kcal}$ yr BP), whereas the $n$ alkanol $A C L$ values $\left(A C L_{\text {alc }}\right)$ fluctuates within a relatively narrow range averaging 23.9.

\section{Discussion}

\subsection{Palaeoenvironment}

In the tropics, peatlands are subject to consistently warm and often humid conditions. Although elevated temperatures facilitate microbial decomposition and rapid turnover of $\mathrm{OM}$, these parameters also increase net primary production (NPP) due to longer growing seasons and associated higher local precipitation (Zheng et al. 2007). Because peat accumulates when NPP outstrips microbial decomposition (Chimner and Ewel, 2005), the overriding dominant control on (sub) tropical peat formation is the extent of waterlogging (Couwenberg et al., 2010). Waterlogging enables anaerobic depositional conditions to prevail that ultimately retards the rate of decomposition and permits OM rich peat sediments to accumulate (Rieley et al., 1996). Even though air temperature and local precipitation determines the rate of NPP, microbial activity is additionally influenced by $\mathrm{OM}$ chemistry and reactivity, soil $\mathrm{pH}$, redox conditions and accessibility to potential decomposers (Schmidt et al., 2011). The Mfabeni peatland began accumulating peat within an interdunal valley lined by a non-permeable clay layer after a palaeo-channel linking Lake St Lucia with the Mfabeni basin was obstructed (Grundling et al., 2013). Once the basin was sealed, persistent groundwater input and local precipitation resulted in extended periods of waterlogging, which allowed for peat to accumulate. Consequently, the physical $\mathrm{C}$ accumulation parameters (linear sedimentation, mass accumulation and carbon accumulation) in core SL6 were used by Baker et al. (2014) to reconstruct changes in sedimentation regimes which they argued were ultimately controlled by climate. 
Fluctuations in TOC concentrations in core SL6 is the measure of changes in OM production, deposition and subsequent preservation in the Mfabeni peat deposit (Baker et al., 2014; Zheng et al., 2007). The periods of relatively elevated TOC concentrations (c. 45.7 - 41.1, 38.0, 23.1, from 14.8 kcal yr BP up to and including the majority of the Holocene; Figures 2 and 3) suggests that conditions were ideal for OM preservation, either as a consequence of high NPP (and high sedimentation rates) or waterlogged anoxic depositional conditions that retarded OM remineralisation, or a combination of both processes. Vegetation types also played a role in OM preservation. Long-chain $n$-alkanes emanating from epicuticular waxes of emergent and terrestrial plants (like grasses and sedges) are more resistant to microbial decomposition when compared to the mid- and short-chain $n$-alkanes from submerged macrophyte and algal sources, respectively (Meyers, 1997; Meyers and Ishiwatari, 1993). Alternatively, during periods of low TOC concentrations (c. 46.9, 30.6 and between 23.1 and $18.4 \mathrm{kcal}$ yr BP; Figures 2 and 3), the dominant cause for low OM preservation would have been low peatland water levels and persistent aerobic microbial remineralisation and, to a less extent, declining NPP, both of which can be linked to the prevailing climatic conditions.

\subsubsection{Organic matter sources}

Since $n$-alkanes are more recalcitrant than other hydrocarbons, they are regarded as one of the more promising indicators of OM sources in sediments. The Mfabeni peat deposit is dominated by long chain $n$-alkanes (>n- $C_{23}$; supplementary data Figure $S 2$ ) suggesting that throughout the peatlands' \pm 47 k years of depositional history, higher terrestrial plants have been the primary source of OM input (Eglinton and Hamilton, 1967; Rieley et al., 1991). Although core SL6 n-alkane $C_{\max }$ values ( supplementary data Table A2) are dominated by $n-C_{29}(36 \%)$ and $n-C_{31}(26 \%)$, which are indicative of both woody plants and graminoids (Jaffé et al., 2001; Mead et al., 2005), at c. 24.5, 14.8 to 9.2 and 8.0 to $7.0 \mathrm{kcal}$ yr BP, the core displays $C_{\max }$ values of either $n-C_{23}$ or $n-C_{25}$, corresponding to dominant OM inputs from submerged macrophytes or mosses (Cranwell, 1984; Ficken et al., 2000; Mead et al., 2005; supplementary data Table A2). Both the $n$-alkanoic acids and $n$-alkanols exhibit bimodal distributions of either short- and mid-chain or mid and long chain homologues, 
respectively, reflecting the mixed origins of both primary plant and secondary microbial sources for these biomarkers (supplementary data Figure S2). When comparing the trends of total concentrations of these biomarkers (supplementary data Figure S3 and Table A3), the $n$-alkanes vs. $n$-alkanoic acids ( $r=0.56, \mathrm{P}=0.01, \mathrm{df}=34)$ and $n$-alkanoic acids vs. $n$-alkanols $(r=0.41, P=0.01, d f=34)$, the trends show strong positive and significant correlations, implying they share a common primary plant source.. However, since the homologue distributions of the $n$-alkanoic acids and $n$-alkanol biomarkers are comparatively different to the $n$-alkane distributions (supplementary data Figure S2), we can infer that these two relatively labile biomarkers have in part been diagenetically altered and their OM source signatures partially overprinted by secondary microbial biomarkers, similarly to the biomarker distributions observed in the Hani peat sequence (Zhou et al., 2010).

Several studies have used the $P_{\text {aq }}$ (Ficken et al., 2000) and $P_{\text {wax }}$ (Zheng et al., 2007) palaeohydrology proxies, in conjunction with other geochemical proxies, to explore shifts between dominant moss and vascular plant input into the northern hemisphere Sphagnum peatlands and reconstruct past water levels (Andersson et al., 2011; Nichols et al., 2006; Zheng et al. 2007; Zhou et al., 2010, 2005). However, in subtropical peatlands, mosses are rare if not completely absent. Consistent with this, the Mfabeni palynology study by Finch and Hill (2008) showed little evidence of moss spores, which leads us to conclude that the mid-chain length $n$-alkanes reported in core SL6, are predominantly of submerged macrophyte origin. The interpretation of the $\mathrm{P}_{\text {wax }}$ proxy, on the other hand, could be complicated by the fact that emergent macrophytes (in particular sedges) thrive in seasonally inundated sub-tropical peatlands, and display homologue distributions similar to terrestrial plants (Ficken et al., 1998, 2000). Nevertheless, during exceptionally high water levels that facilitate proliferation of submerged plants, the oxic water / sediment interface is reduced substantially resulting in a lack of adequate oxygen to support vascular plant roots (Nichols et al., 2009). As a consequence, submerged and emergent macrophytes are unlikely to occupy the same habitat at the same time. Consistent with this, core SL6 exhibits a significant negative correlation between $\mathrm{P}_{\text {aq }}$ and $P_{\text {wax }}(r=-0.98 ; P=0.01 ; d f=37 ;$ Figure 2$)$, validating the antagonistic link between these two 
proxies, and their expediency for understanding past peatland hydrology. The majority of the $\mathrm{P}_{\mathrm{aq}}$ values in core SL6 falls within the dominant emergent plant range (0.1-0.4; Ficken et al., 2000) with the exception of c. $44.5-42.6,29.7,26.1-23.1,16.7-7.1$ and $2.2 \mathrm{kcal}$ yr BP where a submerged / floating plant signature is exhibited $(>0.4)$, and present day sediments indicating a dominant source of terrestrial OM input $(<0.1)$.

Although Gagosian and Peltzer (1986) observed overall longer chain $n$-alkane wax lipids in vascular land plants growing in warm climates, compared to cold climate species, other authors (Andersson et al., 2011; Bush and McInerney, 2013; Schefuß et al., 2003; Zhou et al., 2010, 2005) have reported that $\mathrm{ACL}_{\text {alk }}$ values respond more strongly to changes in moisture. Core SL6 exhibits a significant negative relationship between $P_{a q}$, and $A C L_{\text {alk }}$ signals $(r=-0.83 ; P=0.01 ; d f=37$; Figure 2$)$, suggesting a causal link between peatland water levels and $\mathrm{ACL}_{\text {alk }}$ values. The relative abundance of different plant species can also impact the $\mathrm{ACL}_{\text {alk }}$ signal by producing distinct $n$-alkane distributions as a result of shifts in plant assemblages in response to changing peatland hydrology (Cranwell, 1974; Schwark et al., 2002). The contemporary local dominant Poaceae (grasses) and Cyperaceae (sedges) present in the peatland today is represented by $\mathrm{ACL}_{\text {alk }}$ and $\mathrm{P}_{\text {wax }}$ core maximums ( 30.8 and 0.94$)$, and $\mathrm{P}_{\mathrm{aq}}$ core minimum (0.06, supplementary Table A2; Figure 2 ) in surface sediments, which validates these proxies as an indicator of palaeovegetation assemblages. Excursions to elevated $A_{C L} L_{\text {alk }}$ values (between c. 41.1 and 33.2, 5.2 and 2.8, and $1.5 \mathrm{kcal}$ yr BP to present), coincides with low $\mathrm{P}_{\text {aq }}$ values (Figure 2), most probably as a result of increased inputs of grasses in response to drier conditions (Cranwell, 1974). This is consistent with the high frequency of local Poaceae macrofossils documented in the Mfabeni palynology study (Finch and Hill, 2008) during the same periods.

$\mathrm{CPI}_{\text {alk }}$ values have often been used to infer palaeoenvironmental conditions that were either conducive or unfavourable for microbial decomposition in temperate, boreal and continental humid peat deposits (Andersson et al., 2011; Routh et al., 2014; Xie et al., 2004; Zheng et al., 2007; Zhou et al., 2005, 2010). These authors attributed the high CPI values to cold conditions that retarded the 
rate of microbial alteration of $n$-alkanes. However, the typically moderate cooling experienced in African low latitude areas (Bard, et al., 1997) during the LGM, which Finch and Hill (2008) specifically attribute to the Mfabeni peatland's proximity to the ocean, resulted in a negligible temperature effect on the rate of microbial decomposition. Nonetheless, it is not only thermal dynamics that dictates the extent of degradation in sub-tropical peatlands, but also lability of OM and the amount of oxygen available during decomposition. The $\mathrm{CPI}_{\text {alk }}$ profile (Figure 2) exhibits an opposite trend to TOC concentrations up until the Pleistocene-Holocene boundary $(r=-0.46 ; P=0.01, d f=23)$, after which both profiles trend positively $(r=0.78, P=0.01, d f=12)$. The opposite trend exhibited during the Pleistocene implies that OM bioreactivity, as opposed to depositional dynamics played the dominant role in peat accumulation in the Mfabeni peatland. Furthermore, the $\mathrm{P}_{\text {aq }}$ signal exhibits a significant negative relationship with $\mathrm{CPI}_{\text {alk }}(\mathrm{r}=-0.51, \mathrm{P}=0.01, \mathrm{df}=37$; Figure 2$)$, which demonstrates that low CPI values are concordant with increases in mid-chain $n$-alkane submerged macrophyte input (e.g. from c. $44.5-41.2,24.5$ and $10.4 \mathrm{kcal} \mathrm{yr} \mathrm{BP;} \mathrm{Figure} \mathrm{2).} \mathrm{Since} \mathrm{the} \mathrm{degree} \mathrm{of} \mathrm{waterlogging} \mathrm{is}$ typically the driving factor for OM preservation in subtropical peats (Rieley et al., 1996), it can be postulated that during periods of elevated TOC concentrations, the extent of waterlogging could have been sufficient to support increased and/or dominant submerged macrophyte populations. This increase of in-situ aquatic plants would have in turn resulted in SOM with relatively lower $\mathrm{CPI}_{\text {alk }}$ signatures owing to less recalcitrant mid-chain $n$-alkanes prevalent in submerged aquatic plants (Meyers, 1997; Meyers and Ishiwatari, 1993).

The reason for the switch to a positive trend between $T O C$ and $\mathrm{CPI}_{\text {alk }}$ profiles during the Holocene is not easily explained, however, the adjustment in peat accumulation dynamics could offer some insights. The shift in average C accumulation rates (see Baker et al., 2014: Figure 4 and details therein) from $12 \mathrm{~g} \mathrm{C} \cdot \mathrm{m}^{-2} \cdot \mathrm{yr}{ }^{-1}$ during the Pleistocene to $32 \mathrm{~g} \mathrm{C} \cdot \mathrm{m}^{-2} \cdot \mathrm{yr}^{-1}$ during the Holocene, suggests an increase in both NPP and OM preservation in the Mfabeni peatland. This trend implies that peat accumulation occurred as a result of high sedimentation rates in the basin. This observation is further supported by the overall increase in $\mathrm{CPI}_{\text {alk }}$ and decreasing $\mathrm{P}_{\mathrm{aq}}$ values (Figure 2 ) recorded 
during the Holocene. All these trends indicate a dominant emergent and terrestrial higher plant $\mathrm{OM}$ source input towards the mid- and late Holocene, and supports the inference of a combined higher NPP and low OM decomposition due to high sedimentation rates, and a refractory OM source. The relatively minor differences between the LGM and Holocene average temperature in the Southern African sub-tropics, compared to higher latitudes (Bard et al., 1997; Chevalier and Chase, 2015; Finch and Hill, 2008), can arguably be the reason for both the $\mathrm{CPI}_{\text {alk }}$ and $\mathrm{ACL}_{\text {alk }}$ proxies exhibiting more dominant moisture variability, as opposed to temperature effects.

\subsubsection{Microbial alteration}

Since microbial decay of $\mathrm{OM}$ tends to be reduced during cool and dry climatic conditions (Kuder and Kruge, 1998), biomarkers that are more susceptible to microbial reworking have previously been employed to reconstruct palaeoenvironmental conditions, mostly in temperate peatlands and lake archives (Bai et al., 2009; Zheng et al., 2007; 2011a, 2011b; Zhou et al., 2005, 2010). The Mfabeni peatland experienced relatively minor variations in temperature during the last glacial and interglacial transition (Finch and Hill, 2008), and C accumulation was mainly controlled by waterlogging and, to a lesser extent, NPP. Consistent with this, the positive and significant relationship between total sat/unsat $F_{F A}$ ratio and TOC concentration $(r=0.36, P=0.05, d f=37$; Figure 3 ) suggests that when there was an increase in C preservation, there was a corresponding increase in microbial alteration of unsaturated $n$-alkanoic acids. This relationship implies that during times of high peatland water levels (and associated anaerobic induced low decomposition rates), temperatures must have also been elevated and although, temperature variations in the Mfabeni peatland did not significantly affect local plant physiology (i.e. increased waxy coatings; $A C L_{\text {alk }}$ ), it did have an effect on microbial decomposition. Chevalier and Chase (2015) analysed 13 regional pollen sequences in the summer rainfall zone of South Africa and concluded that a positive relationship existed between temperature and rainfall in the north eastern parts of South Africa, at least during the Late Pleistocene. Additionally, since short chain unsaturated $n$-alkaonic acids $\left(n-C_{16} \& n-C_{18}\right)$ are more susceptible to microbial alteration than their long chain saturated counterparts (Haddad et al., 
1992), the rapidly decreasing 16:1/16:0 and 18:1/18:0 $n$-alkanoic acids (supplementary data Table

A2) observed down core in the Mfabeni, reinforces the sat/unsat $\mathrm{FA}_{\mathrm{A}}$ ratios as a reliable proxy for microbial reworking and palaeotemperature reconstructions in subtropical peatlands.

According to Zhou et al. (2010), high peat $\mathrm{CPI}_{\mathrm{FA}}$ values can indicate either elevated preservation of the original OM plant material or overprinting of secondary biomarker acids produced by microbes during diagenesis. Because $n$-alkanoic acids are highly susceptible to degradation (Meyers, 2003), it could be argued that high $\mathrm{CPI}_{\mathrm{FA}}$ values in core SL6 indicate intensive microbial reworking of primary plant acids into secondary microbial acids. The positive and significant statistical correlation between $\mathrm{CPI}_{\mathrm{FA}}$ and sat/unsat $\mathrm{FA}_{\mathrm{FA}}$ data sets $(r=0.32, \mathrm{P}=0.05, \mathrm{df}=37$; Figure 3$)$ implies that during periods of increased microbial reworking of unsaturated $n$-alkanoic acids, and therefore higher ambient temperatures, the corresponding higher $\mathrm{CPI}_{\mathrm{FA}}$ values result from an increase in postdepositional secondary microbial acids production, at the expense of the primary plant acids. Furthermore, both the $A C L_{\text {alc }}$ and $A C L_{F A}$ data sets trend negatively to sat/unsat $F A$ data set $(r=-0.34$, $P=0.05, d f=37 ; r=-0.41, P=0.01, d f=37$, respectively; Figure 3$)$. This reinforces the palaeoenvironmental link established above between lower plant wax $A L C_{a l c}$ and $A C L_{F A}$ values during periods of high peatland water levels and temperature induced increases in microbial reworking of $n$-alkanoic acids.

\subsection{Palaeoenvironment reconstruction}

By combining the palaeoenvironmental proxies in core SL6, we can surmise the climatic controls on peat forming processes within the Mfabeni peatland. To facilitate comparisons between the bulk geochemical (Baker et al., 2014) and molecular proxies, the palaeoreconstruction will be divided up into linear sedimentation rate (LSR) stages as outlined in Baker et al. (2014) namely, LSR stage 1 (c. 47.0 -32.4 kcal yr BP); LSR stage 2 (c. $32.1-27.9$ kcal yr BP); LSR stage 3 (c. $27.6-20.3 \mathrm{kcal}$ yr BP); LSR Stage 4 (c. 19.8 -10.4 kcal yr BP); LSR stage 5 (c. 10.2 kcal yr BP - present). 
LSR stage 1 (c. $47.0-32.4$ kcal yr BP; $805-620 \mathrm{~cm}$ ) is characterised by low to average $\mathrm{CPI}_{\text {alk }}$ values, predominant above average $\mathrm{ACL}_{\text {alk }}$ values and emergent / terrestrial plant signal (low $\mathrm{P}_{\text {aq }}$ and high $P_{\text {wax }}$ values), with the exception of between c. 44.5 and $42.6 \mathrm{kcal}$ yr BP (Figure 2). The sat/unsat $\mathrm{FA}_{\mathrm{A}}$ and $\mathrm{CPI}_{\mathrm{FA}}$ proxy signals (Figure 3) exhibits predominantly elevated values, suggesting increased microbial reworking and relatively elevated ambient air temperatures. The raised $\mathrm{P}_{\text {aq }}$ (and low $\mathrm{P}_{\mathrm{wax}}$ ) values between c. 44.5 and $42.6 \mathrm{kcal}$ yr BP correspond with elevated TOC concentrations (48.8\%) and sat/unsat $\mathrm{FA}_{\mathrm{A}}(70.5)$ core maximum, implying a period of extensive waterlogging and elevated temperatures, which provided an ideal habitat for the proliferation of submerged macrophytes. The simultaneous A2 warming event (c. $44.5 \mathrm{kcal}$ yr BP and Heinrich 5; H5) has been documented in Antarctic ice cores (Blunier et al., 1998; Stocker, 2000), which coincides with a sharp increase in SST in a Mozambique Channel marine core MD79257 (Figure 4; $20^{\circ} 24^{\prime}$ S; $26^{\circ} 20^{\prime} \mathrm{E}$; Bard et al., 1997; Sonzogni et al., 1998). This trend supports the inference of a discernible increase in submerged aquatic macrophyte input in response to raised water levels.

The $\mathrm{H} 4$ event occurred at c. $38 \mathrm{kcal}$ yr BP, while the A1 warming event was recorded in Antarctic cores at c. $37 \mathrm{kcal}$ yr BP (Blunier et al., 1998; Stocker, 2000) coinciding with elevated SST in the Mozambique Channel MD79257 core (Bard et al., 1997; Sonzogni et al., 1998), and arguably increased continental rainfall in the region. However, biomarker proxies in core SL6 imply that water levels in the peatland during the A1 event were not elevated sufficiently to exclude emergent and terrestrial plants $\left(P_{a q}=0.2\right)$, but rather resulted in a switch to a seasonally inundated peatland, with increased contribution of sedges and grasses (Baker at al., 2014; Kotze and O'Connor, 2000), as supported by elevated $A C L_{a l k}$ values during the second half of $L S R$ stage 1 . The sat/unsat ${ }_{F A}$ and $C P I_{F A}$ proxies (Figure 3) decreases in the lead up to the $\mathrm{H} 4$ event, but rebounds after the $\mathrm{A} 1$ warming event signifying a slight cooling during the $\mathrm{H} 4$ event, and return to elevated ambient temperatures.

LSR stage 2 (c. $\mathbf{3 2 . 1}-\mathbf{2 7 . 9} \mathrm{kcal}$ yr BP; $615-\mathbf{5 2 0} \mathrm{cm}$ ) exhibits parameters which imply an overall drier and cooler climate compared to LSR stage 1 . The TOC signal decreases to the core minimum $(4.5 \%$; 
c. $30.6 \mathrm{kcal}$ yr BP; H3), coinciding with an increase in sandy peat deposition, low sat/unsat ${ }_{\mathrm{FA}}$ and $\mathrm{CPI}_{\mathrm{FA}}$ values, suggesting cool and dry climatic conditions (Figures 2 and 3). After c. $30.6 \mathrm{kcal} \mathrm{yr} \mathrm{BP,}$ the TOC signal increases steadily, coinciding with decreases in $\mathrm{CPI}_{\text {alk }}, \mathrm{ACL}_{\text {alk }}, \mathrm{P}_{\text {wax }}$ and increases in $\mathrm{P}_{\text {aq }}$ values signalling an increase in aquatic submerged plant input due to an increase in peatland water levels. The spike in sat/unsat $\mathrm{FA}_{\mathrm{FA}}$ and $\mathrm{CPI}_{\mathrm{FA}}$ (Figure 3 ) values indicate simultaneous increase in ambient air temperature, corroborated by a spike in MD79257 marine core SST data (Bard et al., 1997; Sonzogni et al., 1998), regional speleothem (Talma and Vogel, 1992), lake (Partridge, 2002), and Vostok Antarctic ice core data (Stocker, 2000) at c. 28 kcal yr BP.

LSR stage 3 (c. $27.6-20.3 \mathrm{kcal}$ yr BP; $515-410 \mathrm{~cm}$ ) displays two very distinctive climatic settings. Between c. 27.6 and $23.1 \mathrm{kcal}$ yr BP, the TOC values continue to increase, with average to low $\mathrm{CPI}_{\text {alk, }}$, fluctuating $A C L_{a k k}$, decreasing $P_{\text {wax }}$ and elevated $P_{a q}$ values, indicating a period of increased waterlogging and dominance of local submerged aquatic plants. The elevated excursion of the palaeohydrology proxies, suggests an intensive period of waterlogging and a relative short $( \pm 3000$ yrs) period of submerged conditions in the Mfabeni peatland, while the sat/unsat $F_{F A}$ proxy (Figure 3 ) displays below average values, thereby implying this period was subject to relatively moderate temperatures. Around c. $23.1 \mathrm{kcal}$ yr BP, a sharp decline in TOC concentrations, coinciding with increased $\mathrm{CPI}_{\mathrm{alk}}, \mathrm{P}_{\text {wax }}$, and a sharp decline in $\mathrm{P}_{\mathrm{aq}}$ occurs, implying minimal waterlogging and a shift to cool and dry glacial conditions. The proxies for microbial reworking trend negatively towards below average values ( $\mathrm{CPI} F \mathrm{FA}$ and sat/unsat $\mathrm{FA}_{\mathrm{A}}$, respectively; Figure 3), indicating a decline in ambient air temperatures. Similar regional climate adjustments to cooler and dry conditions were reported by Baker et al (2014), Bard et al. (1997), Blunier et al. (1998), Finch and Hill (2008) and Holmgren et al (2003) during the LGM.

LSR stage 4 (c. $19.8-10.4$ kcal yr BP; $405-310 \mathrm{~cm}$ ) sees a steady decrease in $\mathrm{CPI}_{\text {alk }}, \mathrm{ACL}_{\text {alk }}$ and $\mathrm{P}_{\text {wax }}$ and recovery in $\mathrm{P}_{\text {aq }}$ values (Figure 2), accompanied by overall increasing TOC values, whereas the proxies for microbial reworking remain low throughout SLR stage $4\left(\mathrm{CPI}_{\mathrm{FA}}\right.$ and sat/unsat $\mathrm{FA}_{\mathrm{A}}$; Figure 3$)$. 
These trends suggest a slow increase in submerged macrophytes due to a gradual change from low glacial water levels to a shallow lacustrine environment leading up to c. $15 \mathrm{kcal}$ yr BP, but stagnant ambient air temperatures till the beginning of the Holocene. During the Antarctic cold reversal (ACR; c. $14.5-12.9 \mathrm{kcal}$ yr BP) the $n$-alkane signals briefly reverse their respective trends suggesting an increase in emergent and terrestrial plant input in response to a brief period of dry conditions, thereafter, a recovery occurs at the onset of the YD (c.12.8 kcal yr BP). While our findings are in agreement with the Antarctic ice cores (Stocker, 2000) and regional stalagmite records (Holmgren et al., 2003; Talma and Vogel, 1992), they are in conflict with other terrestrial climate records stemming from the African tropics (Schefuß et al., 2005; Talbot et al, 2007), regional inland escarpment peatland (Norström et al., 2009), Eastern escarpment Wonderkrater spring mound (Truc et al., 2013) and the winter rainfall area in the south Western Cape (Chase et al., 2011). These archives recorded a deglacial reversal during the YD, as opposed to the ACR. In further support of our findings, recent investigations by Schefuß et al. (2011) observed increased continental summer rainfall output in the Zambezi catchment area (marine core GeoB9307-3, $18^{\circ} 33.9^{\prime} \mathrm{S}, 37^{\circ} 22.8^{\prime} \mathrm{E}$ ) during the $\mathrm{H} 1$ and YD events. Similarly, the Mozambique Channel core SST archive recorded a sharp temperature increase after c. 15 kyr BP (Figure 4; Bard et al., 1997; Sonzogni et al., 1998), with a reversal during the ACR and a pause in the increasing SST corresponding to the YD event, before continuing on a positive trend into the Holocene.

LSR stage 5 (c. $10.2 \mathrm{kcal}$ yr BP - present; $305-10 \mathrm{~cm}$ ) spans the Holocene and is characterised by overall elevated C accumulation rates compared to the preceding glacial period (Baker et al., 2014). Finch and Hill (2008) observed high frequency of arboreal Podocarpus species during the early Holocene, and rapid increase in swamp forest pollen and a predominant local Pteridophyta signal during the Holocene Altithermal ( 8-6 kcal yr BP), followed by a decline in Podocarpus and increases in Poaceae and Cyperaceae species towards the end of mid-Holocene (Figure 4). They used these pollen sequences to infer an initial moist and cool local climate, and then shift to warm and moist conditions during the Holocene Altithermal, followed by a cooler and drier climate 
towards the end of the mid-Holocene. The first half of LSR stage 5 exhibits fluctuating $\mathrm{CPI}_{\text {alk }}, \mathrm{ACL}_{\text {alk }}$ and predominant submerged macrophyte signals, accompanied by a steady decline of the $\mathrm{CPI}_{\mathrm{FA}}$ proxy until c. $7.1 \mathrm{kcal}$ yr BP (Figure 3), coinciding with the lowest Holocene TOC concentration (19.2\%). The East coast palynology record in Lake Eteza similarly recorded a drying event between c. 8 and $7 \mathrm{kcal}$ yr BP (Neumann et al., 2010), coinciding with a drop in SST in the Mozambique Channel after c. 8 kcal yr BP (Bard et al., 1997; Sonzogni et al., 1998).

The $\mathrm{P}_{\mathrm{aq}}$ and $\mathrm{P}_{\text {wax }}$ values switch to a predominant emergent plant signal after c. $7.1 \mathrm{kcal} \mathrm{yr} \mathrm{BP}$, concordant with a rebound in TOC (Figure 2) and increases in both microbial activity proxies (CPI FA and sat/unsat $\mathrm{FA}_{\mathrm{A}} ;$ Figure 3 ). The $\delta \mathrm{D} n-\mathrm{C}_{31}$ alkane, terrestrial leaf wax input and SST proxies in marine core GeoB9307-3 (Schefuß et al., 2011) and SST of marine core MD79257 (Figure 4; Bard et al., 1997, Sonzogni et al., 1998) reveal an increase in SSTs and continental rainfall between c.5.5 and $4 \mathrm{kcal}$ yr BP. Similarly, Neumann et al. $(2010,2008)$ interpreted the palynological profile in Lake Sibaya and Lake Eteza, on the northern Kwazulu Natal coast to symbolize a moist and warm mid-Holocene period. We propose that due to changes in the Holocene $\mathrm{C}$ accumulation dynamics (compared to the glacial period; Baker et al., 2014), higher Holocene NPP resulted in increased C preservation without the obligatory permanent waterlogging required for high OM preservation during the late Pleistocene. This change in environmental and deposition dynamics resulted in moderate precipitation (i.e. seasonal as opposed to permanent inundation or shallow lake levels) conducive for vascular plant growth in the Mfabeni peatland while maintaining relatively high $\mathrm{C}$ preservation. This would explain the terrestrial and emergent plant (low $\mathrm{P}_{\mathrm{aq}}$ and high $\mathrm{P}_{\mathrm{wax}}$ ) signal being concordant with elevated TOC values during the mid- to late Holocene period.

The late-Holocene is characterised by an elevated $\mathrm{CPI}_{\text {alk }}$ profile, which steadily increases until c. 2.2 kcal yr BP, concordant with predominant emergent plant signals, elevated TOC values and declining $\mathrm{CPI}_{\mathrm{FA}}$ and sat/unsat $\mathrm{FA}$ ratios. Finch and Hill (2008) observed peripheral swamp forest taxa maximum in the beginning of the late Holocene, which they concluded was a response to warm and moist 
conditions and the steady decline in arboreal pollen attributed to increased anthropogenic agricultural practices (Figure 4). After c. $3 \mathrm{kcal}$ yr BP, they proposed the establishment of open savannah / woodland vegetation as a result of a drying trend. Similarly, Neumann et al. (2010) observed a drying trend in the proximal Lake Eteza after c. $3.6 \mathrm{kcal}$ yr BP. The Mfabeni record, however, suggests an increase in emergent sedges and terrestrial grasses (corresponding to elevated TOC) between c. 4.4 and $2.2 \mathrm{kcal}$ yr BP, arguably in response to increased moisture availability, coeval to tropical Indian Ocean GeoB937-3 marine core precipitation $\delta$ D and SST proxies (Schefuß et al., 2011). At c. $2.2 \mathrm{kcal}$ yr BP, an abrupt increase in $\mathrm{P}_{\text {aq }}$ values occurs, corresponding to decreases in $\mathrm{ACL}_{\text {alk }}$ and $\mathrm{P}_{\text {wax }}$ values, implying a sudden increase in water levels and aquatic plant input. Although Talma and Vogel (1992) recorded a late Holocene constant temperature range, varying only within +1 and $-2^{\circ} \mathrm{C}$, a discernable escalation in ambient air temperatures was observed at c. $2.5 \mathrm{kcal}$ yr BP in the Cango Cave speleothem archive. We surmise, due to the elevated TOC values and submerged plant signature observed in core SL6, shallow lacustrine conditions occurred after the recorded transition to open savannah vegetation by Finch and Hill (2008). Consistent with this, Walther and Neumann (2011) recorded a definitive change to a savannah environment only after c. 2 kcal yr BP in two proximal coastal plain sediments, namely Lake Sibaya and Kosi Bay, citing dry conditions on the northern Kwazulu Natal coast as the cause, which has persisted till today.

Climate variability during the late Pleistocene in the southern subtropics of Africa was influenced by the mean latitudinal position of the ITCZ, either as result of southward displacement during high latitude Northern Hemisphere cooling events (Johnson et al., 2002; Schefuß et al., 2011) or northward displacement in response to direct insolation forcing (Castañeda et al., 2009; Johnson et al., 2002). However, due to the close correlation between the Mozambique Channel marine records (Bard et al., 1997; Schefuß et al., 2011; Sonzogni et al., 1998) and palaeoenvironmental proxies in the Mfabeni peatland, the primary forcing mechanism on the northern Kwazulu Natal coastal palaeoenvironment appears to have been the evaporation and advection of moisture from the adjacent Indian Ocean, as established by Truc et al. (2013) for the wider SE African region. The 
overriding climatic control of the Indian Ocean SST on this area could explain the general anti-phase inter-hemispheric trends exhibited in the Mfabeni record, which lends support to the theory that the northern and southern hemispheres exhibited opposite climatic responses to the possible switching on/ off of the global oceanic thermohaline circulation system during the late Pleistocene (Bard et al., 1997; Blunier et al, 1998; Stocker 2000). However, this theory can only be fully tested once further high resolution climate archive investigations are undertaken.

\section{Conclusions}

Biomarker distributions were analysed in a c. 47 kyr old continuous peat sequence to elucidate the late Pleistocene and Holocene palaeoenvironment and reconstruct the climate on the northern Kwazulu Natal coast of South Africa. The peat sequence is dominated by higher terrestrial plant input, with the exception of increased submerged macrophyte input during periods of shallow lacustrine conditions (c. 44.5 to $42.6 ; 29.7 ; 26.0$ to $23.1 ; 16.7$ to 7.0 and $2.2 \mathrm{kcal}$ yr BP) representing discernible increases in precipitation. The statistical negative relationship between $\mathrm{P}_{\mathrm{aq}}$ and $A C L_{\text {alk, }}$, $\mathrm{CPI}_{\text {alk }}$ proxies, suggests strong effects of moisture availability, as opposed to temperature fluctuations on local plant physiology. This is arguably due to relatively moderate glacial cooling, but prominent fluctuations in precipitation in the Mfabeni peatland. Nonetheless, by employing temperature sensitive sat/unsat $\mathrm{FA}_{\mathrm{FA}}$ and $\mathrm{CPI}_{\mathrm{FA}}$ proxies, we were able to disentangle temperature and precipitation fluctuations on a local scale, and observed a general positive trend between increased temperature and moisture availability throughout the core. We report high variability in moisture availability but subdued temperatures during the late Pleistocene. In contrast, the Holocene is characterised by elevated ambient air temperatures and precipitation in comparison to the preceding glacial period, with the exception of a millennial scale cooling event at c. $7.1 \mathrm{kcal} \mathrm{yr}$ BP.

The close association between the Mozambique Channel marine records and the Mfabeni palaeoproxies implies the dominant control on the SE African climate to have been the adjacent Indian Ocean SST, as opposed to the changes in the ITCZ latitudinal positioning and /or solar 
insulation since the late Pleistocene. However, there is a need for further high resolution studies of marine and terrestrial archives to firmly establish the climate forcing mechanism of the adjacent Indian Ocean SST on past continental precipitation and temperatures in the region.

\section{Acknowledgments}

Alistair Clulow assisted with field access and site identification. A Russian peat corer was loaned by

Piet-Louis Grundling. iSimangaliso Authority and Ezemvelo KZN Wildlife granted park access and sampling permits. We thank an anonymous reviewer and Phil Meyers whose suggestions were very helpful in improving the manuscript. The project was supported through a bilateral funding agreement by the Swedish Research Link-South Africa program (Grant 348-2009-6500). Student support was provided by the Department of Science and Technology through the National Research Foundation and InKaba yeAfrica. This is an Inkaba ye Africa publication no. 121 and AEON publication no. 141.

\section{References}

Al-Mutlaq, K.F., Standley, L.J., Simoneit, B.R.T., 2008. Composition and sources of extractable organic matter from a sediment core in Lake Kivu, East African rift valley. Appl. Geochemistry 23, 10231040. DOI:10.1016/j.apgeochem.2007.07.013.

Anderson, J.A.R., Muller, J., 1975. Palynological study of a Holocene peat and a Miocene coal deposit from NW Borneo. Review of Palaeobotany and Palynology 19 (4), 291-317.

Andersson, R. A., Kuhry, P., Meyers, P., Zebühr, Y., Crill, P., Mörth, M., 2011. Impacts of paleohydrological changes on $\mathrm{n}$-alkane biomarker compositions of a Holocene peat sequence in the eastern European Russian Arctic. Org. Geochem. 42, 1065-1075. DOI:10.1016/j.orggeochem.2011.06.020.

Andersson, R. a., Meyers, P. A., 2012. Effect of climate change on delivery and degradation of lipid biomarkers in a Holocene peat sequence in the Eastern European Russian Arctic. Org. Geochem. 53, 63-72. DOI:10.1016/j.orggeochem.2012.05.002.

Baker, A., Routh, J., Blaauw, M., Roychoudhury, a. N., 2014. Geochemical records of palaeoenvironmental controls on peat forming processes in the Mfabeni peatland, Kwazulu Natal, South Africa since the Late Pleistocene. Palaeogeogr. Palaeoclimatol. Palaeoecol. 395, 95-106. DOI:10.1016/j.palaeo.2013.12.019. 
Bai, Y., Fang, X., Nie, J., Wang, Y., Wu, F., 2009. A preliminary reconstruction of the paleoecological and paleoclimatic history of the Chinese Loess Plateau from the application of biomarkers. Palaeogeogr. Palaeoclimatol. Palaeoecol. 271, 161-169. DOI:10.1016/j.palaeo.2008.10.006.

Bard, E., Rostek, F., Sonzogni, C., 1997. Interhemispheric synchrony of the last deglaciation inferred from alkenone palaeothermometry. Nature. 385, 707-710. DOI:10.1038/385707a0.

Bate, G.C., Taylor, R.H., 2008. Sediment salt-load in the St Lucia Estuary during the severe drought of 2002-2006. Environ. Geol. 55, 1089-1098. DOI:10.1007/s00254-007-1057-3.

Bendle, J., Kawamura, K., Yamazaki, K., Niwai, T., 2007. Latitudinal distribution of terrestrial lipid biomarkers and $\mathrm{n}$-alkane compound-specific stable carbon isotope ratios in the atmosphere over the western Pacific and Southern Ocean. Geochim. Cosmochim. Acta 71, 5934-5955. DOI:10.1016/j.gca.2007.09.029.

Bendle, J. A., Kawamura, K., Yamazaki, K., 2006. Seasonal changes in stable carbon isotopic composition of $\mathrm{n}$-alkanes in the marine aerosols from the western North Pacific: Implications for the source and atmospheric transport. Geochim. Cosmochim. Acta 70, 13-26. DOI:10.1016/j.gca.2005.08.01.

Blaauw, M., Christeny, J.A., 2011. Flexible paleoclimate age-depth models using an autoregressive gamma process. Bayesian Anal. 6, 457-474. DOI:10.1214/11-BA618

Blunier, T., Chappellaz, J., Schwander, J., DaÈllenbach, A., Stauffer, B., Stocker, T. F., Raynaud, D., Jouzel, J., Clausen, H. B., Hammer, C. U., Johnsen, S. J., 1998. Asynchrony of Antarctic and Greenland climate change during the last glacial period. Nature 394, 739-743. DOI:10.1038/29447.Botha, G., Porat, N., 2007. Soil chronosequence development in dunes on the southeast African coastal plain, Maputaland, South Africa. Quat. Int. 162-163, 111-132. DOI:10.1016/j.quaint.2006.10.028.

Botha, G., Porat, N., 2007. Soil chronosequence development in dunes on the southeast African coastal plain, Maputaland, South Africa. Quat. Int. 162-163, 111-132. doi:10.1016/j.quaint.2006.10.028

Bush, R.T., Mclnerney, F. A., 2013. Leaf wax n-alkane distributions in and across modern plants: Implications for paleoecology and chemotaxonomy. Geochim. Cosmochim. Acta 117, 161-179. DOI:10.1016/j.gca.2013.04.016.

Carr, A.S., Boom, A., Grimes, H.L., Chase, B.M., Meadows, M.E., Harris, A., 2014. Leaf wax n-alkane distributions in arid zone South African flora: Environmental controls, chemotaxonomy and palaeoecological implications. Org. Geochem. 67, 72-84.

DOI:10.1016/j.orggeochem.2013.12.004.

Castañeda, I.S., Werne, J.P., Johnson, T.C., Filley, T.R., 2009. Late Quaternary vegetation history of southeast Africa: The molecular isotopic record from Lake Malawi. Palaeogeogr. Palaeoclimatol. Palaeoecol. 275, 100-112. DOI:10.1016/j.palaeo.2009.02.008.

Chase, B.M., Meadows, M.E., 2007. Late Quaternary dynamics of southern Africa's winter rainfall zone. Earth-Science Rev. 84, 103-138. DOI:10.1016/j.earscirev.2007.06.002. 
Chase, B.M., Thomas, D.S.G., 2007. Multiphase late Quaternary aeolian sediment accumulation in western South Africa: Timing and relationship to palaeoclimatic changes inferred from the marine record. Quat. Int. 166, 29-41. DOI:10.1016/j.quaint.2006.12.005.

Chase, B.M., Meadows, M.E., Carr, A.S., Reimer, P.J., 2010. Evidence for progressive Holocene aridification in southern Africa recorded in Namibian hyrax middens: Implications for African Monsoon dynamics and the "African Humid Period". Quat. Res. 74, 36-45.

DOI:10.1016/j.yqres.2010.04.006.

Chase, B.M., Quick, L.J., Meadows, M.E., Scott, L., Thomas, D.S.G., Reimer, P.J., 2011. Late glacial interhemispheric climate dynamics revealed in South African hyrax middens. Geology 39, 1922. DOI:10.1130/G31129.1.

Chase, B.M., Scott, L., Meadows, M.E., Gil-Romera, G., Boom, A., Carr, A.S., Reimer, P.J., Truc, L., Valsecchi, V., Quick, L.J., 2012. Rock hyrax middens: A palaeoenvironmental archive for southern African drylands. Quat. Sci. Rev. 56, 107-125. DOI:10.1016/j.quascirev.2012.08.018.

Chevalier, M., Chase, B.M., 2015. Southeast African records reveal a coherent shift from high- to low-latitude forcing mechanisms along the east African margin across last glacial-interglacial transition. Quat. Sci. Rev. 125, 117-130. doi:10.1016/j.quascirev.2015.07.009

Chimner, R. A., Ewel, K.C., 2005. A tropical freshwater wetland: II. Production, decomposition, and peat formation. Wetl. Ecol. Manag. 13, 671-684. DOI:10.1007/s11273-005-0965-9.

Clulow, A. D., Everson, C.S., Mengistu, M.G., Jarmain, C., Jewitt, G.P.W., Price, J.S., Grundling, P.L., 2012. Measurement and modelling of evaporation from a coastal wetland in Maputaland, South Africa. Hydrol. Earth Syst. Sci. 16, 3233-3247. DOI:10.5194/hess-16-3233-2012.

Cranwell, P.A., House, T.F., 1984. Lipid geochemistry of sediments from Upton Broad, a small productive lake. Org. Geochem. 7, 25-37. DOI:10.1016/0146-6380(84)90134-7.

Cranwell, P. A., 1974. Monocarboxylic acids in lake sediments: Indicators, derived from terrestrial and aquatic biota, of paleoenvironmental trophic levels. Chem. Geol. 14, 1-14.

DOI:10.1016/0009-2541(74)90092-8.

Couwenberg, J., Dommain, R., Joosten, H., 2010. Greenhouse gas fluxes from tropical peatlands in south-east Asia. Glob. Chang. Biol. 16, 1715-1732. doi:10.1111/j.1365-2486.2009.02016.x

Dommain, R., Couwenberg, J., Glaser, P.H., Joosten, H., Suryadiputra, I.N.N., 2014. Carbon storage and release in Indonesian peatlands since the last deglaciation. Quat. Sci. Rev. 97, 1-32. doi:10.1016/j.quascirev.2014.05.002

Dommain, R., Couwenberg, J., Joosten, H., 2011. Development and carbon sequestration of tropical peat domes in south-east Asia: Links to post-glacial sea-level changes and Holocene climate variability. Quat. Sci. Rev. 30, 999-1010. doi:10.1016/j.quascirev.2011.01.018

Eglinton, G., Hamilton, R.J., 1967. Leaf Epicuticular Waxes. Science 156, 1322-1335. DOI: 10.1126/science.156.3780.1322.

Ficken, K.J., Farrimond, P., 1995. Sedimentary lipid geochemistry of Framvaren: impacts of a changing environment. Mar. Chem. 51, 31-43. DOI:10.1016/0304-4203(95)00045-S 
Ficken, K.J., Barber, K.E., Eglinton, G., 1998. Lipid biomarker, $\delta 13 \mathrm{C}$ and plant macrofossil stratigraphy of a Scottish montane peat bog over the last two millennia. Org. Geochem. 28, 217-237. DOI:10.1016/S0146-6380(97)00126-5.

Ficken, K.J., Li, B., Swain, D.L., Eglinton, G., 2000. An n-alkane proxy for the sedimentary input of submerged / floating freshwater aquatic macrophytes. Org. Geochem. 31, 745-749. DOI:10.1016/S0146-6380(00)00081-4

Finch, J.M. 2005. Late Quaternary palaeoenvironments of the Mfabeni peatland, Northern KwazuluNatal: Master's thesis. Unpublished MSc thesis. University of KwaZulu-Natal, Pietermaritzburg.

Finch, J.M., Hill, T.R., 2008. A late Quaternary pollen sequence from Mfabeni Peatland, South Africa: Reconstructing forest history in Maputaland. Quat. Res. 70, 442-450. DOI:10.1016/j.yqres.2008.07.003.

Gagosian, R.B., Peltzer, E.T., 1986. The importance of atmospheric input of terrestrial material to deep sea sediments. Org. Geochem. 10, 661-669. DOI:10.1016/S0146-6380(86)80002-X.

Grundling, P.L. 2001. The quaternary peat deposits of maputaland, northern kwazulu-natal, south africa: Categorisation, chronology and utilisation. Unpublished MSc thesis. University of Johannesburg.

Grundling, P.L., Grootjans, A. P., Price, J.S., Ellery, W.N., 2013. Development and persistence of an African mire: How the oldest South African fen has survived in a marginal climate. Catena 110, 176-183. DOI:10.1016/j.catena.2013.06.004.

Haddad, R.I., Martens, C.S., Farrington, J.W., 1992. Quantifying early diagenesis of fatty acids in a rapidly accumulating coastal marine sediment. Org. Geochem. 19, 205-216. DOI:10.1016/01466380(92)90037-X.

Hemming, S.R., 2004. Heinrich events: Massive late Pleistocene ditritus layers of the North Atlanitc and their global cliamate imprint. Rev. Geophys. 42. DOI:10.1029/2003RG000128.1.

Hillaire-Marcel, C., de Vernal, A., 2007. Introduction Methods in Late Cenozoic Paleoceanography: Introduction. Dev. Mar. Geol. 1, 1-15. doi:10.1016/S1572-5480(07)01005-6

Holmgren, K., Lee-Thorp, J. A., Cooper, G.R.J., Lundblad, K., Partridge, T.C., Scott, L., Sithaldeen, R., Talma, A. S., Tyson, P.D., 2003. Persistent millennial-scale climatic variability over the past 25,000 years in Southern Africa. Quat. Sci. Rev. 22, 2311-2326. DOI:10.1016/S02773791(03)00204-X.

Holzkämper, S., Holmgren, K., Lee-Thorp, J., Talma, S., Mangini, A., Partridge, T., 2009. Late Pleistocene stalagmite growth in Wolkberg Cave, South Africa. Earth Planet. Sci. Lett. 282, 212221. DOI:10.1016/j.epsl.2009.03.016.

Hu, J., Peng, P., Jia, G., Fang, D., Zhang, G., Fu, J., Wang, P., 2002. Biological markers and their carbon isotopes as an approach to the paleoenvironmental reconstruction of Nansha area, South China Sea , during the last 30 ka. Org. Geochem. 33, 1197-1204. DOI:10.1016/S01466380(02)00082-7. 
Huang, Y., Street-Perrott, A.F., Perrott, A.R., Metzger, P., Eglinton, G., 1999. Glacial - interglacial environmental changes inferred from molecular and compound-specific $\delta 13 \mathrm{C}$ analyses of sediments from Sacred Lake, Mt . Kenya. Geochim. Cosmochim. Acta 63, 1383-1404. DOI:10.1016/S0016-7037(99)00074-5.

Ishiwatari, R., Yamamoto, S., Uemura, H., 2005. Lipid and lignin/cutin compounds in Lake Baikal sediments over the last $37 \mathrm{kyr}$ : implications for glacial-interglacial palaeoenvironmental change. Org. Geochem. 36, 327-347. DOI:10.1016/j.orggeochem.2004.10.009.

Jaffe, R., Mead, R., Hernandez, M.E., Peralba, M.C., Ja, R., Diguida, O.A., 2001. Origin and transport of sedimentary organic matter in two subtropical estuaries: a comparative, biomarker-based study. Org. Geochem. 32, 507-526. DOI:10.1016/S0146-6380(00)00192-3.

Johnson, T.C., Brown, E.T., McManus, J., Barry, S., Barker, P., Gasse, F., 2002. A high-resolution paleoclimate record spanning the past 25,000 years in southern East Africa. Science 296, 113132. DOI:10.1126/science.1070057.

Kotze, D.C., O'Connor, T.G., 2000. Vegetation Variation within and among Palustrine Wetlands along an Altitudinal Gradient in KwaZulu-Natal , South Africa. Plant Ecol. 146, 77-96.

DOI:10.1023/A:1009812300843.

Kristen, I., Wilkes, H., Vieth, A., Zink, K.-G., Plessen, B., Thorpe, J., Partridge, T.C., Oberhänsli, H., 2010. Biomarker and stable carbon isotope analyses of sedimentary organic matter from Lake Tswaing: evidence for deglacial wetness and early Holocene drought from South Africa. J. Paleolimnol. 44, 143-160. DOI:10.1007/s10933-009-9393-9.

Kuder, T., Kruge, M.A., 1998. Preservation of biomolecules in sub-fossil plants from raised peat bogs - a potential paleoenvironmental proxy. Org. Geochem. 29, 1355-1368. DOli:10.1016/S01466380(98)00092-8.

Kurnianto, S., Warren, M., Talbot, J., Kauffman, B., Murdiyarso, D., Frolking, S., 2014. Carbon accumulation of tropical peatlands over millennia: A modeling approach. Glob. Chang. Biol. 431-444. doi:10.1111/gcb.12672

Lee-Thorp, J.A., Holmgren, K., Lauritzen, S.E., Linge, H., Moberg, A., Partridge, T.C., Stevenson, C., Tyson, P.D., 2001. Rapid climate shifts in the southern African interior throughout the mid to late Holocene. Geophys. Res. Lett. 28, 4507-4510. DOI:10.1029/2000GL012728.

Mead, R., Xu, Y., Chong, J., Jaffé, R., 2005. Sediment and soil organic matter source assessment as revealed by the molecular distribution and carbon isotopic composition of $n$-alkanes. Org. Geochem. 36, 363-370. DOI:10.1016/j.orggeochem.2004.10.003.

Meadows, M., Baxter, A., Parkington, J., 1996. Late Holocene environments at Verlorenvlei, Western Cape Province, South Africa. Quat. Int. 33, 81-95. DOI:10.1016/1040-6182(95)00092-5.

Meadows, M.E., Baxter, A.J., 1999. Late Quaternary palaeoenvironments of the southwestern Cape, South Africa: A regional synthesis. Quat. Int. 57-58, 193-206. DOI:10.1016/S10406182(98)00060-3.

Meadows, M., 2001. The role of Quaternary environmental change in the evolution of landscapes: case studies from southern Africa. Catena 42, 39-57. DOI:10.1016/S0341-8162(00)00115-6. 
Meyers, P. A., 1997. Organic geochemical proxies of paleoceanographic, paleolimnologic, and paleoclimatic processes. Org. Geochem. 27, 213-250. DOI:10.1016/S0146-6380(97)00049-1.

Meyers, P. A., 2003. Applications of organic geochemistry to paleolimnological reconstructions: A summary of examples from the Laurentian Great Lakes. Org. Geochem. 34, 261-289. DOI:10.1016/S0146-6380(02)00168-7.

Meyers, P. A., Ishiwatari, R., 1993. Lacustrine organic geochemistry-an overview of indicators of organic matter sources and diagenesis in lake sediments. Org. Geochem. 20, 867-900. DOI:10.1016/0146-6380(93)90100-P.

Meyers, P.A., Kawka, O.E., 1984. Geolipid, pollen and diatom stratigraphy in postglacial lacustrine sediments. Org. Geochem. 6, 727-732.

Mucina, L., Adams, J.B., Knevel, I.C., Rutherford, M.C., Powrie, L.W., Bolton, J.J., van der Merwe, J.H., Anderson, R.J., Bornman, T.G., le Roux, A., Janssen, J.A.M., 2006. Coastal vegetation of South Africa, in: Mucina, L., Rutherford, M.C. (Eds.), The Vegetation of South Africa, Lesotho and Swaziland. South African National Biodiversity Institute, Pretoria, pp. 658-696.

Nash, D.J., Meadows, M.E., 2012. Africa, in: Metcalfe, S.E., Nash, D.J. (Eds.), Quaternary Environmental Change in the Tropics. John Wiley \& Sons, Ltd., UK, pp. 79-150.

Neumann, F.H., Stager, J.C., Scott, L., Venter, H.J.T., Weyhenmeyer, C., 2008. Holocene vegetation and climate records from Lake Sibaya, KwaZulu-Natal (South Africa). Rev. Palaeobot. Palynol. 152, 113-128. DOI:10.1016/j.revpalbo.2008.04.006.

Neumann, F.H., Scott, L., Bousman, C.B., van As, L., 2010. A Holocene sequence of vegetation change at Lake Eteza, coastal KwaZulu-Natal, South Africa. Rev. Palaeobot. Palynol. 162, 39-53. DOI:10.1016/j.revpalbo.2010.05.001.

Nichols, J.E., Booth, R.K., Jackson, S.T., Pendall, E.G., Huang, Y., 2006. Paleohydrologic reconstruction based on n-alkane distributions in ombrotrophic peat. Org. Geochem. 37, 1505-1513. DOI:10.1016/j.orggeochem.2006.06.020.

Nichols, J.E., Walcott, M., Bradley, R., Pilcher, J., Huang, Y., 2009. Quantitative assessment of precipitation seasonality and summer surface wetness using ombrotrophic sediments from an Arctic Norwegian peatland. Quat. Res. 72, 443-451. DOI:10.1016/j.yqres.2009.07.007.

Norström, E., Scott, L., Partridge, T.C., Risberg, J., Holmgren, K., 2009. Reconstruction of environmental and climate changes at Braamhoek wetland, eastern escarpment South Africa, during the last 16,000 years with emphasis on the Pleistocene-Holocene transition. Palaeogeogr. Palaeoclimatol. Palaeoecol. 271, 240-258. DOI:10.1016/j.palaeo.2008.10.018.

Ogura, K., Machihara, T., Takada, H., 1990. Diagenesis of biomarkers in Biwa Lake sediments over 1 million years. Org. Geochem. 16, 805-813. DOI:10.1016/0146-6380(90)90119-K.

Page, S.E., Rieley, J.O., Banks, C.J., 2011. Global and regional importance of the tropical peatland carbon pool. Glob. Chang. Biol. 17, 798-818. doi:10.1111/j.1365-2486.2010.02279.x 
Pancost, R.D., Boot, C.S., 2004. The palaeoclimatic utility of terrestrial biomarkers in marine sediments. Mar. Chem. 92, 239-261. DOI:10.1016/j.marchem.2004.06.029.

Partridge, T.C., 2002. Were Heinrich events forced from the southern hemisphere? S. Afr. J. Sci. 98, $43-46$.

Peters, K.E., Walters, C.C., Moldowan, J.M., 2004. The Biomarker Guide: Volume 1, Biomarkers and Isotopes in the Environment and Human History. Cambridge University Press.

Porat, N., Botha, G., 2008. The luminescence chronology of dune development on the Maputaland coastal plain, southeast Africa. Quat. Sci. Rev. 27, 1024-1046.

DOI:10.1016/j.quascirev.2008.01.017.

Preston-Whyte, R.A., Tyson, P.D., 1998. The atmosphere and weather of southern Africa. Oxford University Press, South Africa.

Ranjan, R.K., Routh, J., Val Klump, J., Ramanathan, A.L., 2015. Sediment biomarker profiles trace organic matter input in the Pichavaram mangrove complex, Southeastern India. Mar. Chem. 171, 44-57.DOI:10.1016/j.marchem.2015.02.001.

Rieley, J.O., Ahmad-Shah, A.A., Brady, M.A., 1996. The Extent and Nature of Tropical Peat Swamps Tropical Lowland Peatlands of Southeast Asia, in: Integrated Planning and Management of Tropical Lowland Peatlands Workshop.

Rieley, G., Collier, R.J., Jones, D.M., Eglinton, G., Eakin, P.A., Fallick, A.E., 1991. Sources of sedimentary lipids deduced from stable carbon-isotope analyses of individual compounds. Nature 352, 425-427. DOI:10.1038/352425a0.

Routh, J., Hugelius, G., Kuhry, P., Filley, T., Tillman, P.K., Becher, M., Crill, P., 2014. Multi-proxy study of soil organic matter dynamics in permafrost peat deposits reveal vulnerability to climate change in the European Russian Arctic. Chem. Geol. 368, 104-117.

DOI:10.1016/j.chemgeo.2013.12.022

Schefuß, E., Ratmeyer, V., Stuut, J.B.W., Jansen, J.H.F., Sinninghe Damsté, J.S., 2003. Carbon isotope analyses of $n$-alkanes in dust from the lower atmosphere over the central eastern Atlantic. Geochim. Cosmochim. Acta 67, 1757-1767. DOI:10.1016/S0016-7037(02)01414-X.

Schefuß, E., Schouten, S., Schneider, R.R., 2005. Climatic controls on central African hydrology during the past 20,000 years. Nature 437, 1003-1006. DOI:10.1038/nature03945.

Schefuß, E., Kuhlmann, H., Mollenhauer, G., Prange, M., Pätzold, J., 2011. Forcing of wet phases in southeast Africa over the past 17,000 years. Nature 480, 509-512. DOI:10.1038/nature10685.

Schmidt, M.W.I., Torn, M.S., Abiven, S., Dittmar, T., Guggenberger, G., Janssens, I. A., Kleber, M., Kögel-Knabner, I., Lehmann, J., Manning, D. A. C., Nannipieri, P., Rasse, D.P., Weiner, S., Trumbore, S.E., 2011. Persistence of soil organic matter as an ecosystem property. Nature 478, 49-56. DOI:10.1038/nature10386.

Schwark, L., Zink, K., Lechterbeck, J., 2002. Reconstruction of postglacial to early Holocene vegetation history in terrestrial Central Europe via cuticular lipid biomarkers and pollen records from lake sediments. Geology 30, 463-466. DOI:10.1130/0091-7613(2002)030<0463. 
Scott, L., Holmgren, K., Partridge, T.C., 2008. Reconciliation of vegetation and climatic interpretations of pollen profiles and other regional records from the last 60 thousand years in the Savanna Biome of Southern Africa. Palaeogeogr. Palaeoclimatol. Palaeoecol. 257, 198-206.

DOI:10.1016/j.palaeo.2007.10.018

Smuts, W.J., 1992. Peatlands of the Natal Mire Complex - goemorphology \& characterization. S. Afr. J. Sci. $88,474-83$.

Sonzogni, C., Bard, E., Rostek, F., 1998. Tropical sea-surface temperatures during the last glacial period: A view based on alkenones in Indian Ocean sediments. Quat. Sci. Rev. 17, 1185-1201. DOI:10.1016/S0277-3791(97)00099-1.

Staub, J.R., Esterle, J.S., 1994. Peat-accumulating depositional systems of Sarawak, East Malaysia. Sedimentary Geology 89 (1-2), 91-106.

Stocker, T.F., 2000. Past and future reorganizations in the climate system. Quat. Sci. Rev. 19, 301319. DOI:10.1016/S0277-3791(99)00067-0.

Stokes, S., Thomas, D.S.G., Washington, R., 1997. Multiple episodes of aridity in southern Africa since the last interglacial period. Nature 388, 154-158. DOI:10.1038/40596.

Strack, M., Waddington, J.M., Turetsky, M., Roulet, N.T., Byrne, K. A., 2008. Northern peatlands, greenhouse gas exchange and climate change, in: Strack, M. (Ed.), Peatlands and Climate Change. International Peat Society, Jyväskylä, Finland, pp. 44-69.

Talbot, M.R., Filippi, M.L., Jensen, N.B., Tiercelin, J.J., 2007. An abrupt change in the African monsoon at the end of the Younger Dryas. Geochemistry, Geophys. Geosystems 8, 1-16. DOI:10.1029/2006GC001465.

Talma, A.S., Vogel, J.C., 1992. Late Quaternary paleotemperatures derived from a speleothem from Cango Caves, Cape Province, South Africa. Quat. Res. 37, 203-213. DOI:10.1016/00335894(92)90082-T.

Taylor, R., Kelbe, B., Haldorsen, S., Botha, G. A., Wejden, B., Været, L., Simonsen, M.B., 2006 a. Groundwater-dependent ecology of the shoreline of the subtropical Lake St Lucia estuary. Environ. Geol. 49, 586-600. DOI:10.1007/s00254-005-0095-y.

Taylor, R., Adams, J.B., Haldorsen, S., 2006b. Primary habitats of the St Lucia Estuarine System, South Africa, and their responses to mouth management. African J. Aquat. Sci. 31, 31-41. DOI:10.2989/16085910609503869

Truc, L., Chevalier, M., Favier, C., Cheddadi, R., Meadows, M.E., Scott, L., Carr, A.S., Smith, G.F., Chase, B.M., 2013. Quantification of climate change for the last 20,000years from Wonderkrater, South Africa: Implications for the long-term dynamics of the Intertropical Convergence Zone. Palaeogeogr. Palaeoclimatol. Palaeoecol. 386, 575-587. DOI:10.1016/j.palaeo.2013.06.024.

Tyson, P.D., Preston-Whyte, R.A., 2000. The Weather and Climate of Southern Africa, 2nd ed. Oxford University Press Incorporated, Cape Town, South Africa. 
Valsecchi, V., Chase, B.M., Slingsby, J. A., Carr, A.S., Quick, L.J., Meadows, M.E., Cheddadi, R., Reimer, P.J., 2013. A high resolution 15,600-year pollen and microcharcoal record from the Cederberg Mountains, South Africa. Palaeogeogr. Palaeoclimatol. Palaeoecol. 387, 6-16.

DOI:10.1016/j.palaeo.2013.07.009.

Venter, C.E., 2003. Vegetation ecology of Mfabeni peat swamp, St Lucia, KwaZulu-Natal. MSc thesis. Botany Department, University of Pretoria. http://repository.up.ac.za/handle/2263/24480.

Vrdoljak, S.M., Hart, R.C., 2007. Groundwater Seeps as Potentially Important Refugia for Freshwater Fishes on the Eastern Shores of Lake St Lucia, KwaZulu-Natal, South Africa. African J. Aquat. Sci. 32, 125-132. DOI:10.2989/AJAS.2007.32.2.3.200.

Wakeham, S.G., Peterson, M.L., Hedges, J.I., Lee, C., 2002. Lipid biomarker fluxes in the Arabian Sea, with a comparison to the equatorial Pacific Ocean. Deep. Res. II 49, 2265-2301. DOI:10.1016/S0967-0645(02)00037-1.

Walther, S.C., Neumann, F.H., 2011. Sedimentology, isotopes and palynology of late Holocene cores from Lake Sibaya and the Kosi Bay system (KwaZulu-Natal, South Africa). South African Geogr. J. 93, 133-153. DOI:10.1080/03736245.2011.591982.

Wang, Y., Zhu, L., Wang, J., Ju, J., Lin, X., 2012. The spatial distribution and sedimentary processes of organic matter in surface sediments of Nam Co, Central Tibetan Plateau. Chinese Sci. Bull. 57, 4753-4764. DOI:10.1007/s11434-012-5500-9.

Xie, S., Nott, C.J., Avsejs, L. A., Maddy, D., Chambers, F.M., Evershed, R.P., 2004. Molecular and isotopic stratigraphy in an ombrotrophic mire for paleoclimate reconstruction. Geochim. Cosmochim. Acta 68, 2849-2862. DOI:10.1016/j.gca.2003.08.025.

Zheng, Y., Zhou, W., Meyers, P. A., Xie, S., 2007. Lipid biomarkers in the Zoigê-Hongyuan peat deposit: Indicators of Holocene climate changes in West China. Org. Geochem. 38, 1927-1940. DOI:10.1016/j.orggeochem.2007.06.012.

Zheng, Y., Zhou, W., Meyers, P.A., 2011a. Proxy value of $n$-alkan-2-ones in the Hongyuan peat sequence to reconstruct Holocene climate changes on the eastern margin of the Tibetan Plateau. Chem. Geol. 288, 97-104. DOI:10.1016/j.chemgeo.2011.06.011.

Zheng, Y., Zhou, W., Liu, X., Zhang, C.L., 2011b. n-Alkan-2-one distributions in a northeastern China peat core spanning the last 16kyr. Org. Geochem. 42, 25-30.

DOI:10.1016/j.orggeochem.2010.10.003

Zhou, W., Xie, S., Meyers, P. A., Zheng, Y., 2005. Reconstruction of late glacial and Holocene climate evolution in southern China from geolipids and pollen in the Dingnan peat sequence. Org. Geochem. 36, 1272-1284. DOI:10.1016/j.orggeochem.2005.04.005.

Zhou, W., Zheng, Y., Meyers, P. A., Jull, a. J.T., Xie, S., 2010. Postglacial climate-change record in biomarker lipid compositions of the Hani peat sequence, Northeastern China. Earth Planet. Sci. Lett. 294, 37-46. DOI:10.1016/j.epsl.2010.02.035. 


\section{Table captions:}

Table 1: Summary of biomarker proxies

\section{Tables:}

Table 1:

\begin{tabular}{|c|c|c|c|c|c|}
\hline Proxy & Acronym & Equation & Background & Indications & References \\
\hline $\begin{array}{c}\text { Carbon preference index } \\
\text { (all) }\end{array}$ & $\mathrm{CPI}$ & $\begin{array}{c}\mathrm{CPI}_{1}=\left[\Sigma\left(\mathrm{C}_{21}-\mathrm{C}_{29}\right) \text { odd }+\Sigma\left(\mathrm{C}_{23}-\mathrm{C}_{31}\right) \text { odd }\right] / 2 \Sigma\left(\mathrm{C}_{22}-\right. \\
\left.\mathrm{C}_{30}\right) \text { even } \\
\mathrm{CP}_{2}=\left[\Sigma\left(\mathrm{C}_{20}-\mathrm{C}_{30}\right) \text { even }+\Sigma\left(\mathrm{C}_{22}-\mathrm{C}_{32}\right) \text { even }\right] / 2 \Sigma\left(\mathrm{C}_{21}\right. \\
\left.-\mathrm{C}_{31}\right) \text { odd }\end{array}$ & $\begin{array}{l}\text { Plants produce leaf wax with odd-over-even } \\
\text { (n-alkane) or even-over-odd ( } n \text {-alkanonic acid \& } \\
n \text {-alkanol) predominance. During diagenesis, } \\
\text { this odd over even or even over odd } \\
\text { characteristic diminishes. }\end{array}$ & $\begin{array}{l}\uparrow \text { Better preserved or less labile OM source } \\
\text { e.g. terrestrial vs submerged OM input; } \\
\downarrow \text { More degraded or more labile OM source }\end{array}$ & $\begin{array}{l}\text { Rieley et al., 1991; Zhou et } \\
\text { al.,2010, 2005; Andersson } \\
\text { et al., } 2012\end{array}$ \\
\hline Average chain length (all) & ACL & $\begin{array}{c}A C L_{1}=(\Sigma[C i] \times \mathrm{i}) / \Sigma[C i], \text { for } \mathrm{i}=23-33 \text { where } \mathrm{Ci}= \\
\text { conc. of } n \text {-alkane containing } \mathrm{i} \text { carbon atoms; } \\
\mathrm{ACL}_{2}=(\Sigma[\mathrm{C} i] \times \mathrm{i}) / \Sigma[\mathrm{C} i], \text { for } \mathrm{I}=22-32 \text { where } \mathrm{Ci}= \\
\text { conc. of } \mathrm{n} \text {-alkanoic acid or } \mathrm{n} \text {-alkanol containing } \mathrm{i} \\
\text { carbon atoms }\end{array}$ & $\begin{array}{l}\text { Plants produce long chain leaf wax layers in } \\
\text { response to drier and warmer conditions. } \\
\text { Changes in ACL trends can be used to elucidate } \\
\text { climatic conditions during photosynthesis. }\end{array}$ & $\begin{array}{l}\uparrow \text { Longer average chain lengths in leaf wax } \\
\text { layers e.g. hotter and drier conditions; } \\
\downarrow \text { shorter average chain lengths e.g. during } \\
\text { cooler and wetter conditions }\end{array}$ & $\begin{array}{c}\text { Gagosian and Peltzer, 1986; } \\
\text { Schefuß et al., 2003; Zhou } \\
\text { et al., 2005; Carr et al., } \\
2014\end{array}$ \\
\hline $\begin{array}{l}\text { Aquatic plant } \\
\text { (n-alkanes only) }\end{array}$ & Paq & $P_{a q}=\frac{C_{23}+C_{25}}{C_{23}+C_{25}+C_{29}+C_{31}}$ & $\begin{array}{l}\text { Aquatic plant leaf waxes are dominated by mid- } \\
\text { chain alkanes }\left(n-C_{23} \& C_{25}\right) \text {. Poq is used to } \\
\text { elucidate relative amounts of aquatic vs. } \\
\text { higher plant input. }\end{array}$ & $\begin{array}{l}\uparrow \text { more aquatic plant OM input e.g. during } \\
\text { higher water levels; } \\
\downarrow \text { More terrestrial plant OM input e.g. during } \\
\text { low water levels }\end{array}$ & $\begin{array}{c}\text { Cranwell, 1984; Ficken et } \\
\text { al., 2000; Zhou et al., 2010, } \\
\text { 2005; Andersson et al., } \\
2011\end{array}$ \\
\hline $\begin{array}{l}\text { Terrestrial plant } \\
\text { (n-alkanes only) }\end{array}$ & $P_{\text {wax }}$ & $P_{\text {wax }}=\frac{C_{27}+C_{29}+C_{31}}{C_{23}+C_{25}+C_{27}+C_{29}+C_{31}}$ & $\begin{array}{l}\text { Emergent and terrestrial plant leaf waxes have } \\
\text { long-chain alkanes }\left(n-C_{27}, C_{29} \text { and } C_{31}\right) . P_{w a x} \\
\text { indicates variation in terrestrial plant input in } \\
\text { relation to bulk plant input. }\end{array}$ & $\begin{array}{c}\text { T higher proportions of terrestrial plant OM } \\
\text { input during low water levels; } \\
\downarrow \text { less terrestrial plant OM input during high } \\
\text { water levels }\end{array}$ & $\begin{array}{l}\text { Eglinton and Hamilton, } \\
\text { 1967; Rieley et al., 1991; } \\
\text { Zheng et al. 2007; } \\
\text { Andersson et al., 2011 } \\
\end{array}$ \\
\hline
\end{tabular}




\section{Figure captions:}

Figure 1: Core SL6, Mfabeni peatland, iSimangaliso Wetland Park, Kwazulu-Natal, South Africa.

Figure 2: SL6 core \%TOC plotted against $n$-alkane proxies, carbon preference index (CPI), average chain length $(A C L)$, aquatic plant $\left(P_{\text {aq }}\right)$ and terrestrial wax $\left(P_{\text {wax }}\right)$ proxies. $T P=$ terrestrial plants, $E P=$ emergent plants and AP = aquatic plants. $\mathrm{H} 1-5=$ Heinrich events (dates from Hemming, 2004); A1 and A2 = Antarctic warming events (Blunier et al., 1998; Stocker, 2000); LGM = Last Glacial Maximum; $A C R=$ Antarctic cold reversal (Stocker, 2000); YD = Younger Dryas; Hol = Holocene.

Figure 3: Core SL6 \% TOC plotted against $n$-alkanol average chain length $\left(\mathrm{ACL}_{\text {alc }}\right), n$-alkanoic acid carbon preference index $\left(\mathrm{CPI}_{\mathrm{FA}}\right)$, average chain length $\left(\mathrm{ACL}_{\mathrm{FA}}\right)$ and total concentration of saturated / unsaturated $n$-alkanoic acids (sat/unsat $\mathrm{FA}_{\mathrm{A}}$ ). $\mathrm{H} 1-5=$ Heinrich events (dates from Hemming, 2004); A1 and A2 = Antarctic warming events (Blunier et al., 1998; Stocker, 2000); LGM = Last Glacial Maximum; $A C R=$ Antarctic cold reversal $($ Stocker, 2000); YD = Younger Dryas; Hol = Holocene.

Figure 4: Comparison between proximal Indian Ocean SST reconstruction, Mfabeni peatland hydrology and temperature proxies and local Mfabeni plant frequencies. (a) Alkenone SST proxy from marine core MD79257 in the Mozambique Channel $\left(20^{\circ} 24^{\prime}\right.$ S; $26^{\circ} 20^{\prime} \mathrm{E}$; Bard et al., 1997). (b) $n-$ Alkane $P_{\text {aq }}$ precipitation and $n$-alkanoic acid total sat/unsat temperature proxy trends from the Mfabeni peat core. (c) Pollen frequencies of 3 most abundant local species in the Mfabeni peatland Poaceae (grasses), Cyperaceae (sedges) and Podocarpus (arboreal forest tree). Time zones MF-1: 44,000 - 33,000 cal yr BP; MF-2a: 33,000 - 17,500 cal yr BP; MF-2b: 17,500 - 11,000 cal yr BP; MF-3: 11,000 - 5,000 cal yr BP; MF-4: 5,000 - present. Modified from Finch and Hill, 2008. 


\section{Figures:}

\section{Figure 1:}

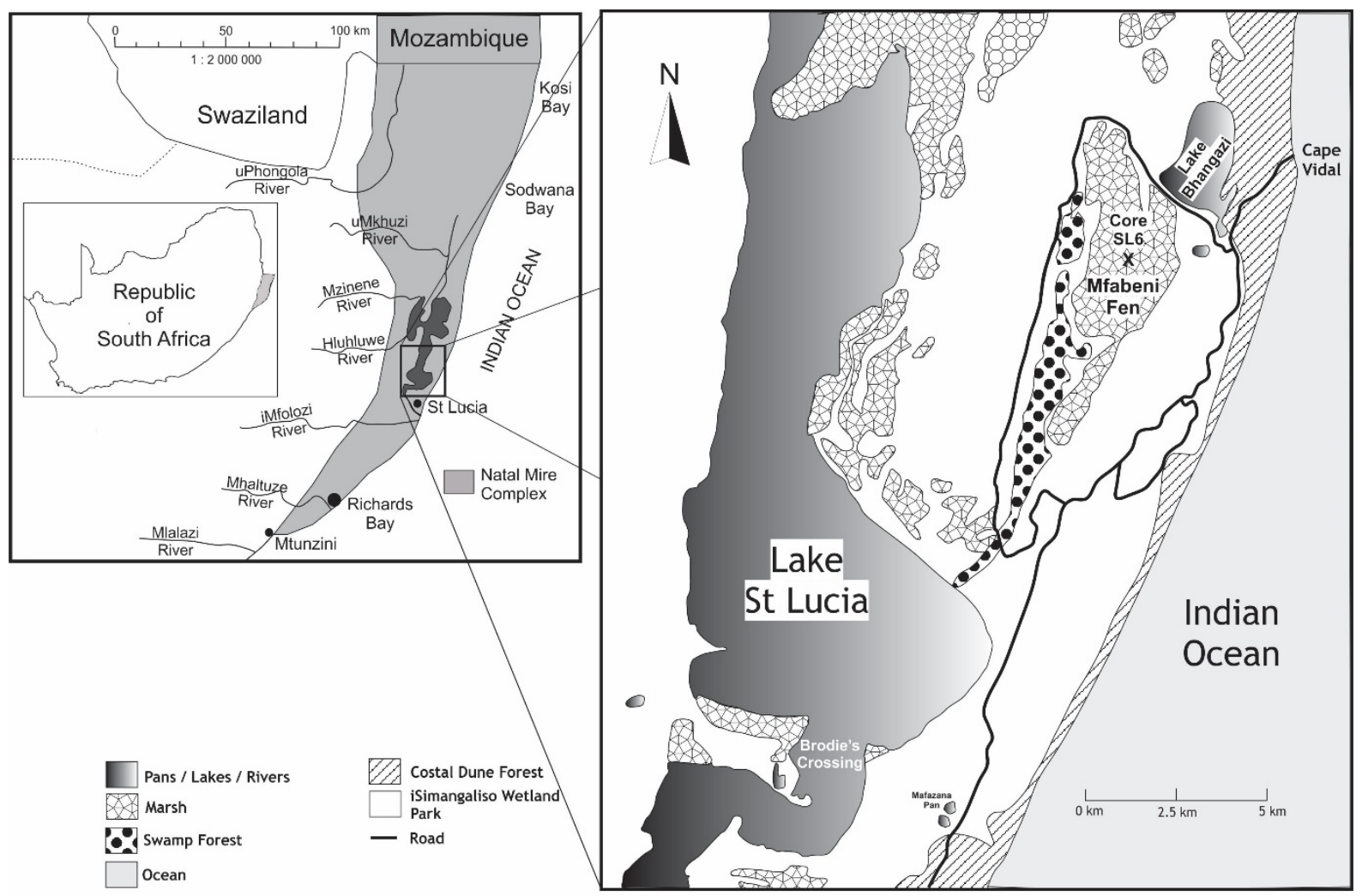




\section{Figure 2:}

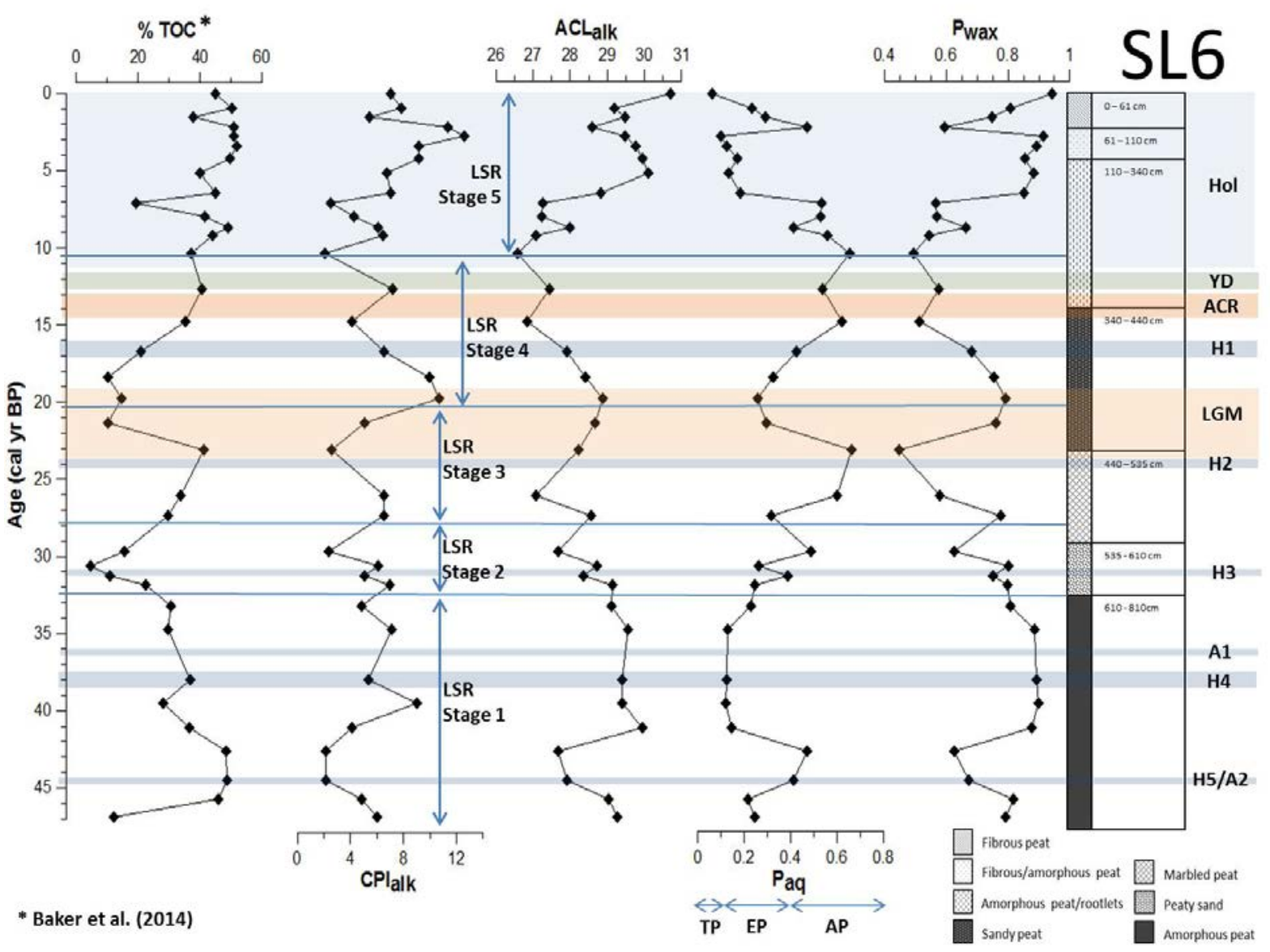




\section{Figure 3:}

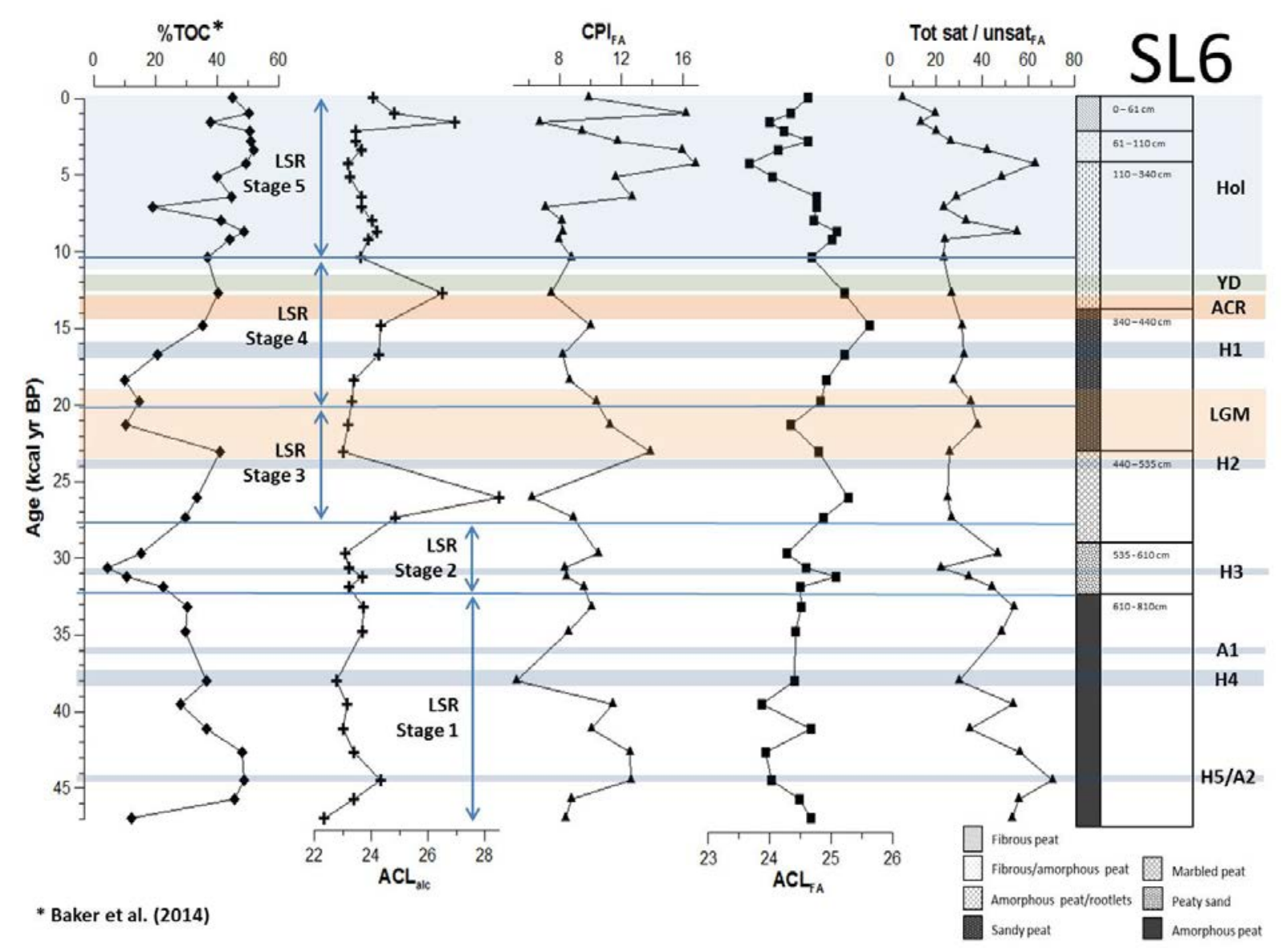


Figure 4:
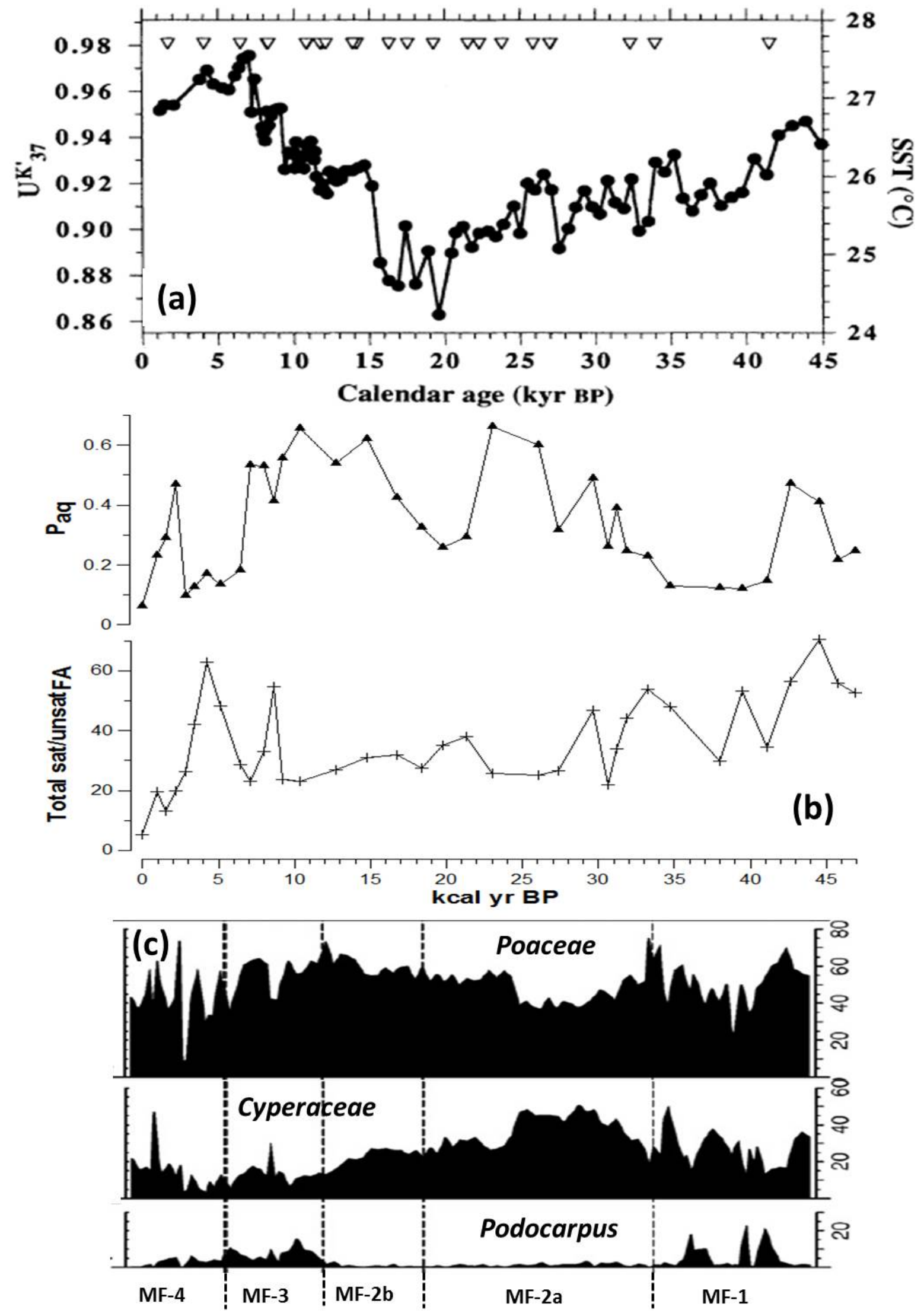


\section{Supplementary data}

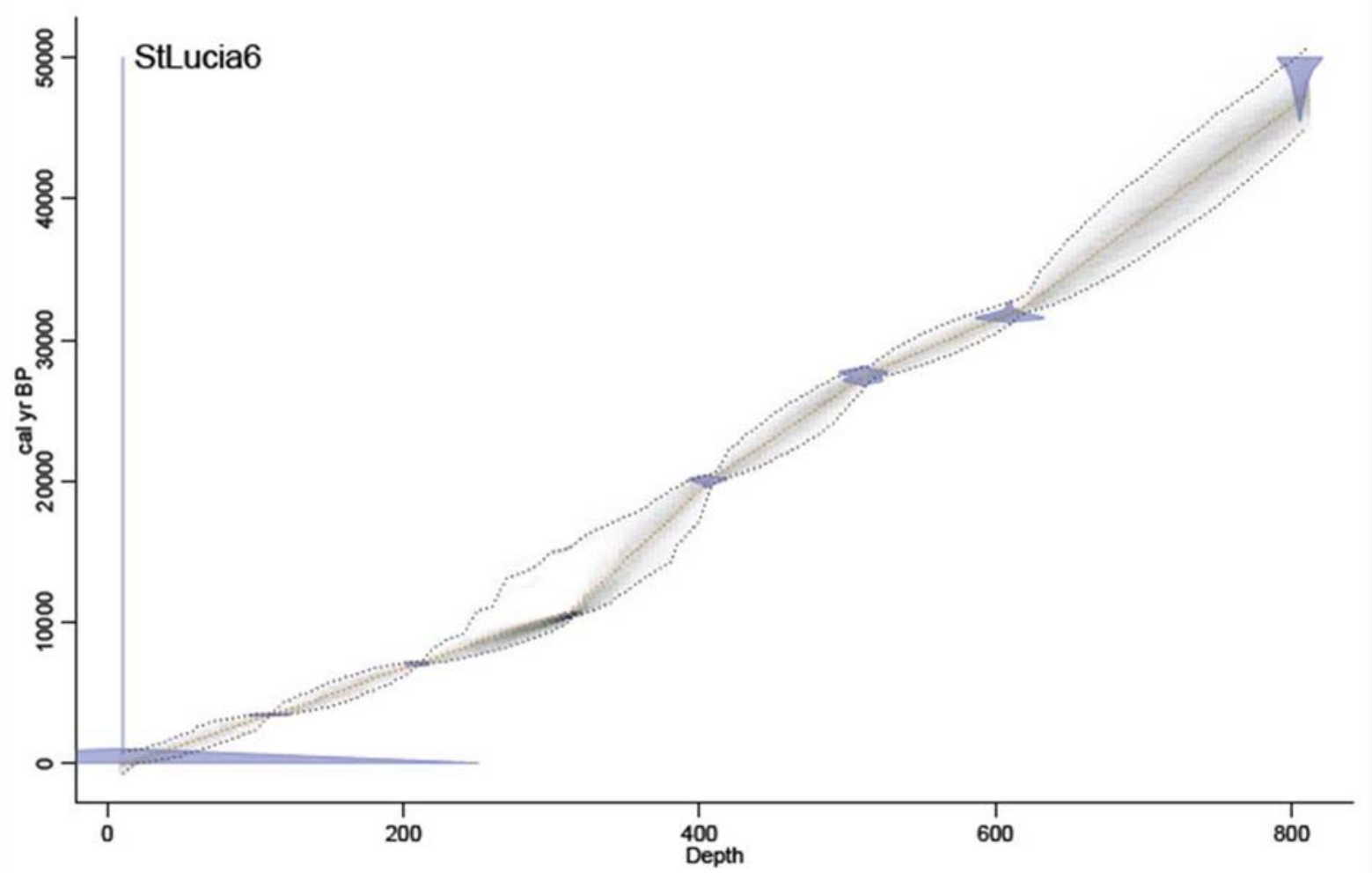

Figure S1: Core SL6 age-depth model with uncertainty ranges (from Baker et al., 2014) 


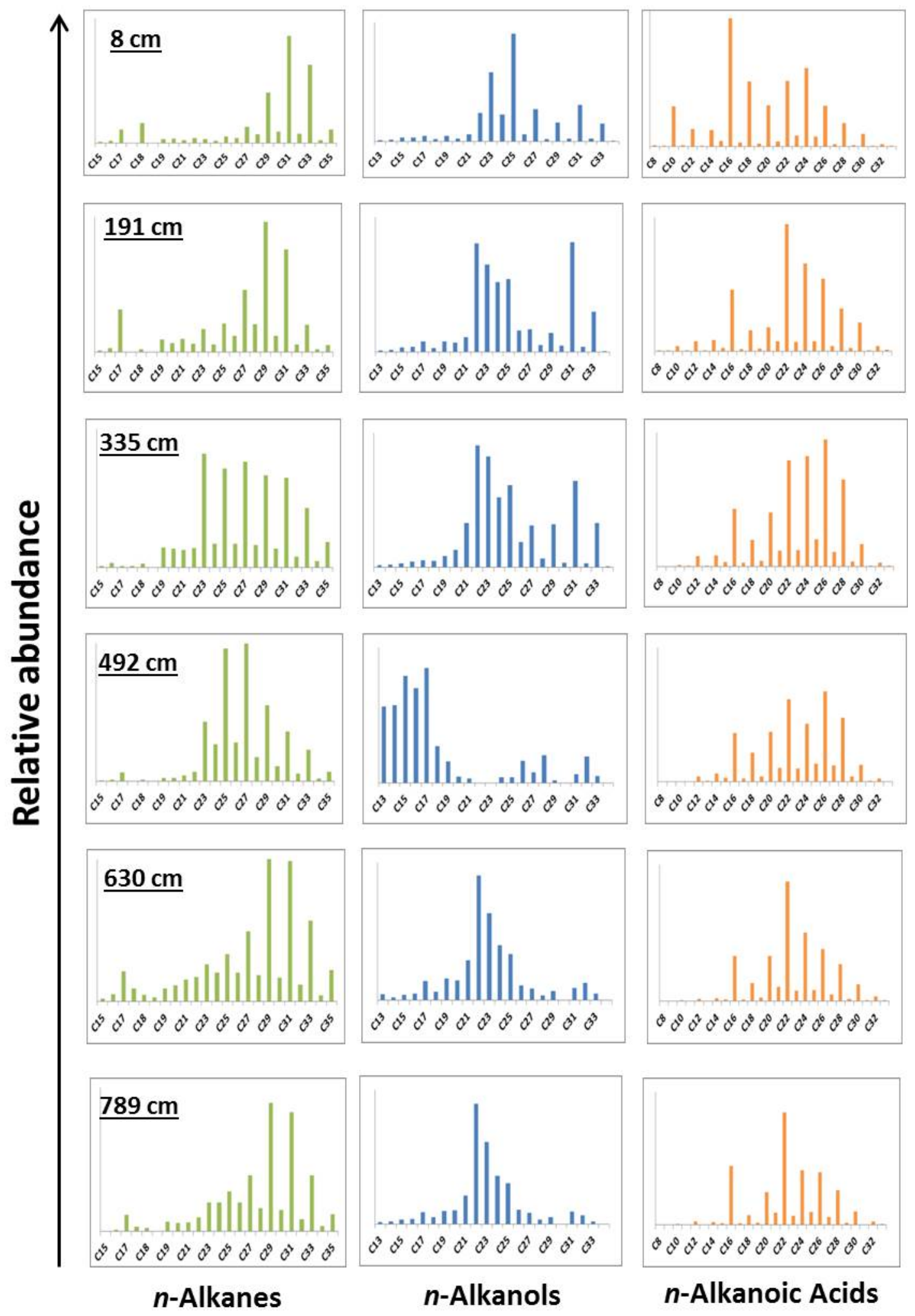

Figure S2: Homologue distributions of n-alkanes, $n$ - alkanols and n-alkanoic acids at specific depth intervals throughout Mfabeni peat core SL6 


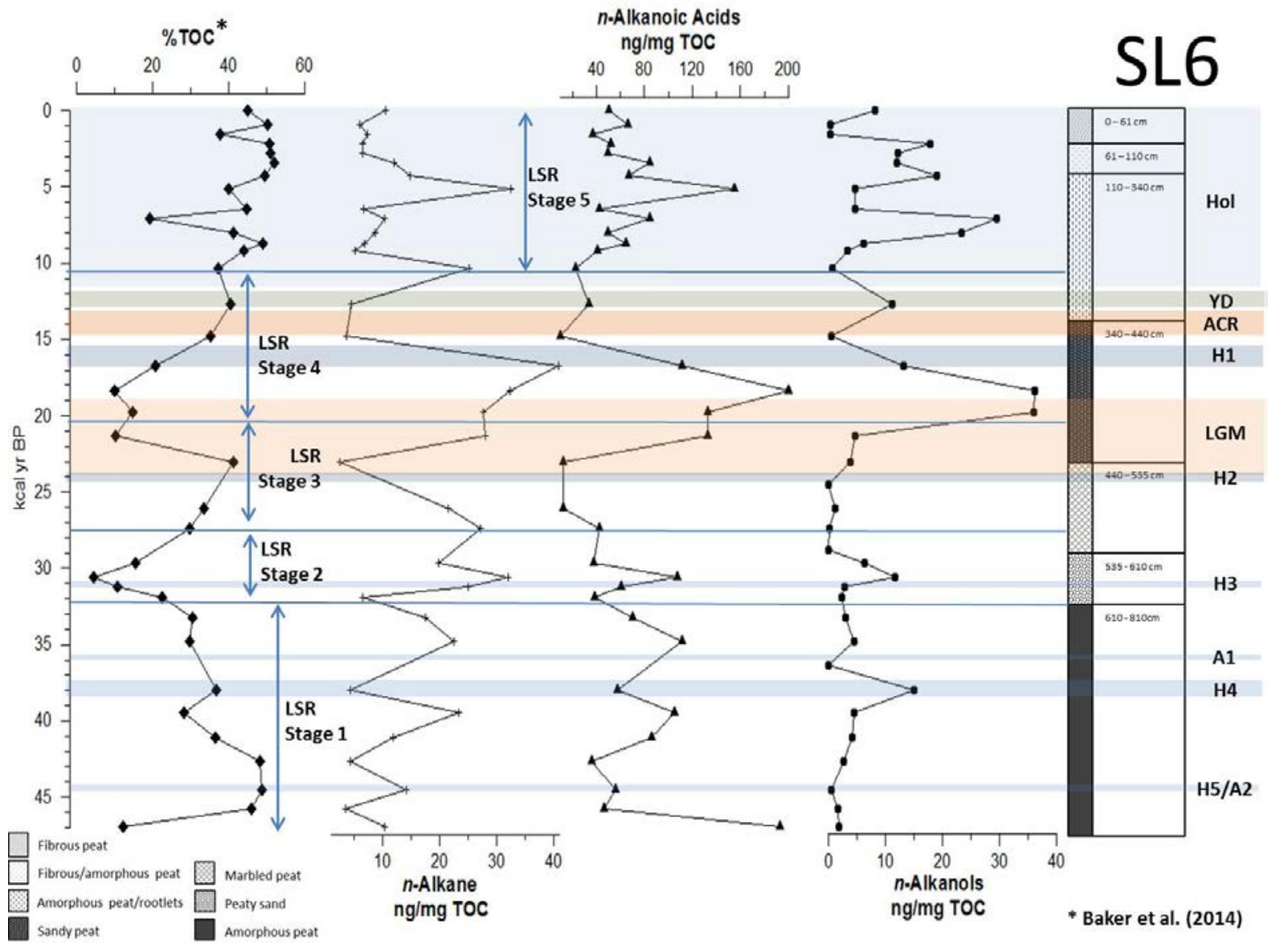

Figure S3: Biomarker concentrations in relation to \% total organic carbon (TOC) in core SL6. H1 - $5=$ Heinrich events (dates from Hemming, 2004); A1 and A2 = Antarctic warming events (Blunier et al., 1998; Stocker, 2000); LGM = Last Glacial Maximum; ACR = Antarctic cold reversal (Stocker, 2000); YD = Younger Dryas; Hol = Holocene. 
Table A1: Chronology of Mfabeni peatland core SL6 with uncalibrated AMS 14C dates, corresponding percentage total organic carbon (TOC) and bulk stable carbon isotope values (from Baker et al., 2014).

\begin{tabular}{cccccc}
\hline $\begin{array}{c}\text { Sample } \\
\text { code }\end{array}$ & $\begin{array}{c}\text { Depth } \\
(\mathbf{c m})\end{array}$ & Material & $\begin{array}{c}\text { uncalibrated } \\
\text { date }\end{array}$ & $\% \mathbf{C}$ & $\boldsymbol{\delta}^{\mathbf{1 3}} \mathbf{C}_{\text {Toc }}$ \\
\hline SL6 10-11 & 10 & Peat & $109 \pm 0.35 \mathrm{pMC}$ & 45.1 & -21.8 \\
SL6 109-110 & 109 & Peat & $3240 \pm 30 \mathrm{BP}$ & 51.9 & -16.8 \\
SL6 209-210 & 209 & Peat & $6170 \pm 30 \mathrm{BP}$ & 19.2 & -24.5 \\
SL6 309-310 & 309 & Peat & $9270 \pm 70 \mathrm{BP}$ & 37.1 & -21.5 \\
SL6 405-406 & 405 & Peat & $16940 \pm 80 \mathrm{BP}$ & 14.7 & -19.1 \\
SL6 510-511 & 510 & Peat & $22800 \pm 130 \mathrm{BP}$ & 29.6 & -18.6 \\
SL6 609-610 & 609 & Peat & $27600 \pm 190 \mathrm{BP}$ & 22.5 & -19.0 \\
SL6 709-710 & 709 & Peat & $>48000 \mathrm{BP}$ & 28.1 & -17.6 \\
SL6 805-806 & 805 & Peat & $49000 \pm 2200 \mathrm{BP}$ & 12.2 & -20.1 \\
\hline
\end{tabular}


Table A2: Biomarker concentrations, distributions and molecular proxy values for core SL6 extracted from the Mfabeni peatland.

\begin{tabular}{|c|c|c|c|c|c|c|c|c|c|c|c|c|c|c|c|c|c|c|c|}
\hline \multirow[b]{2}{*}{$\begin{array}{l}\text { Depth } \\
(\mathrm{cm})\end{array}$} & \multirow[b]{2}{*}{$\begin{array}{c}\text { Age } \\
k \text { cal BP }\end{array}$} & \multirow[b]{2}{*}{$\%$ TOC } & \multicolumn{6}{|c|}{ n-Alkanes } & \multicolumn{4}{|c|}{ n-Alkanols } & \multicolumn{7}{|c|}{ n-Alkanoic Acids } \\
\hline & & & $\begin{array}{c}\text { Tot conc. } \\
\mathrm{ng} / \mathrm{mg} \text { ToC }\end{array}$ & $c_{\max }$ & $\mathrm{CPI}_{1}$ & $\mathrm{ACL}_{1}$ & $P_{39}$ & $\mathbf{P}_{\text {wax }}$ & $\begin{array}{c}\text { Tot conc. } \\
\text { ng/mg ToC }\end{array}$ & $c_{\max }$ & $\mathrm{CPI}_{2}$ & $\mathrm{ACl}_{2}$ & $\begin{array}{c}\begin{array}{c}\text { Tot conc. } \\
\text { ng/mg ToC }\end{array} \\
\end{array}$ & $c_{\max }$ & $\mathrm{CPI}_{2}$ & $\mathrm{ACL}_{2}$ & C16:1/C16:0 & C18:1/C18:0 & $\begin{array}{l}\text { Total Sat / } \\
\text { Unsat conc. }\end{array}$ \\
\hline 8 & 0.0 & 45.1 & 10.4 & 31 & 7.0 & 31 & 0.06 & 0.94 & 8.1 & 25 & 0.3 & 24 & 50.7 & 16 & 9.9 & 25 & 0.130 & 0.375 & 5.1 \\
\hline 41 & 0.9 & 50.3 & 6.0 & 31 & 7.8 & 30 & 0.23 & 0.81 & 0.3 & 23 & 0.3 & 25 & 66.6 & 22 & 16.2 & 24 & 0.029 & 0.127 & 19.4 \\
\hline 57 & 1.5 & 37.8 & 7.3 & 31 & 5.5 & 30 & 0.29 & 0.75 & 0.2 & 32 & 1.7 & 27 & 37.0 & 22 & 6.7 & 24 & 0.021 & 0.167 & 13.2 \\
\hline 76 & 2.2 & 50.8 & 6.5 & 25 & 11.4 & 29 & 0.47 & 0.60 & 17.8 & 23 & 0.5 & 23 & 51.6 & 22 & 9.4 & 24 & 0.008 & 0.091 & 19.8 \\
\hline 92 & 2.8 & 51.0 & 6.4 & 29 & 12.6 & 30 & 0.10 & 0.92 & 12.1 & 23 & 0.5 & 23 & 49.8 & 24 & 11.8 & 25 & 0.004 & 0.047 & 26.4 \\
\hline 108 & 3.4 & 51.9 & 12.0 & 31 & 9.2 & 30 & 0.13 & 0.89 & 11.9 & 23 & 0.4 & 24 & 84.5 & 22 & 15.9 & 24 & 0.009 & 0.044 & 42.2 \\
\hline 134 & 4.2 & 49.6 & 14.8 & 33 & 9.2 & 30 & 0.17 & 0.86 & 19.0 & 22 & 0.8 & 23 & 67.1 & 22 & 16.9 & 24 & 0.003 & 0.013 & 62.9 \\
\hline 157 & 5.1 & 40.0 & 32.6 & 31 & 6.8 & 30 & 0.13 & 0.88 & 4.6 & 23 & 0.7 & 23 & 154.6 & 22 & 11.7 & 24 & 0.004 & 0.007 & 48.1 \\
\hline 191 & 6.4 & 44.8 & 6.6 & 29 & 7.1 & 29 & 0.18 & 0.85 & 4.7 & 31 & 0.7 & 24 & 42.5 & 22 & 12.7 & 25 & 0.004 & 0.061 & 28.8 \\
\hline 209 & 7.1 & 19.2 & 10.3 & 25 & 2.5 & 28 & 0.53 & 0.57 & 29.6 & 23 & 0.8 & 24 & 84.3 & 16 & 7.1 & 25 & 0.004 & 0.070 & 23.2 \\
\hline 237 & 8.0 & 41.3 & 8.6 & 25 & 4.3 & 28 & 0.53 & 0.57 & 23.3 & 22 & 0.7 & 24 & 49.3 & 22 & 8.1 & 25 & 0.001 & 0.041 & 33.0 \\
\hline 257 & 8.7 & 49.0 & 6.7 & 29 & 6.1 & 29 & 0.41 & 0.66 & 6.1 & 31 & 0.5 & 24 & 64.9 & 22 & 8.2 & 25 & 0.001 & 0.030 & 54.8 \\
\hline 273 & 9.2 & 44.0 & 5.1 & 25 & 6.5 & 28 & 0.56 & 0.54 & 3.3 & 24 & 1.7 & 24 & 40.9 & 26 & 8.0 & 25 & 0.001 & 0.047 & 23.7 \\
\hline 309 & 10.4 & 37.1 & 25.1 & 23 & 2.1 & 28 & 0.65 & 0.49 & 0.6 & 23 & 0.5 & 24 & 22.9 & 24 & 8.8 & 25 & 0.003 & 0.094 & 23.0 \\
\hline 335 & 12.7 & 40.6 & 4.5 & 25 & 7.2 & 29 & 0.54 & 0.57 & 11.1 & 22 & 0.6 & 26 & 33.4 & 26 & 7.5 & 25 & 0.000 & 0.039 & 26.7 \\
\hline 355 & 14.8 & 35.3 & 3.6 & 23 & 4.1 & 28 & 0.62 & 0.51 & 0.5 & 31 & 0.5 & 24 & 10.2 & 22 & 10.0 & 26 & 0.000 & 0.016 & 31.0 \\
\hline 375 & 16.7 & 20.7 & 40.8 & 27 & 6.5 & 29 & 0.42 & 0.68 & 13.1 & 31 & 0.5 & 24 & 111.2 & 22 & 8.2 & 25 & 0.002 & 0.020 & 32.0 \\
\hline 390 & 18.4 & 10.1 & 32.4 & 29 & 10.0 & 29 & 0.33 & 0.75 & 36.2 & 22 & 0.7 & 23 & 200.1 & 22 & 8.6 & 25 & 0.002 & 0.026 & 27.5 \\
\hline 404 & 19.8 & 14.7 & 27.6 & 29 & 10.7 & 29 & 0.26 & 0.79 & 35.9 & 22 & 0.8 & 23 & 132.9 & 22 & 10.4 & 25 & 0.000 & 0.016 & 35.0 \\
\hline 424 & 21.3 & 10.3 & 28.1 & 29 & 5.0 & 29 & 0.29 & 0.76 & 4.7 & 22 & 1.1 & 23 & 132.5 & 22 & 11.3 & 24 & 0.002 & 0.029 & 37.9 \\
\hline 450 & 23.1 & 41.1 & 2.4 & 33 & 2.6 & 30 & 0.66 & 0.45 & 3.9 & 23 & 0.8 & 23 & 12.2 & 22 & 13.9 & 25 & 0.001 & 0.048 & 25.6 \\
\hline 492 & 26.1 & 33.5 & 21.4 & 27 & 6.5 & 28 & 0.60 & 0.58 & 1.2 & 17 & 2.3 & 28 & 12.6 & 26 & 6.2 & 25 & 0.000 & 0.017 & 25.0 \\
\hline 510 & 27.4 & 29.6 & 27.1 & 27 & 6.5 & 29 & 0.32 & 0.78 & 0.1 & 22 & 1.6 & 25 & 42.8 & 22 & 8.9 & 25 & 0.000 & 0.033 & 26.5 \\
\hline 559 & 29.7 & 15.5 & 19.8 & 27 & 2.4 & 28 & 0.49 & 0.63 & 6.3 & 22 & 1.7 & 23 & 37.6 & 22 & 10.5 & 24 & 0.000 & 0.006 & 46.7 \\
\hline 580 & 30.6 & 4.5 & 32.1 & 29 & 6.1 & 29 & 0.26 & 0.80 & 11.7 & 22 & 1.9 & 23 & 107.8 & 22 & 8.3 & 25 & 0.000 & 0.108 & 22.0 \\
\hline 595 & 31.2 & 10.7 & 25.1 & 29 & 5.0 & 29 & 0.39 & 0.75 & 2.8 & 22 & 1.3 & 24 & 60.4 & 22 & 8.4 & 25 & 0.000 & 0.020 & 33.9 \\
\hline 609 & 31.9 & 22.5 & 6.5 & 31 & 6.9 & 30 & 0.25 & 0.80 & 2.3 & 22 & 1.1 & 23 & 38.5 & 22 & 9.6 & 24 & 0.003 & 0.012 & 44.0 \\
\hline 630 & 33.2 & 30.4 & 17.4 & 29 & 4.9 & 30 & 0.23 & 0.81 & 3.0 & 22 & 1.1 & 24 & 70.1 & 22 & 10.1 & 25 & 0.001 & 0.009 & 53.9 \\
\hline 649 & 34.8 & 29.7 & 22.4 & 29 & 7.1 & 30 & 0.13 & 0.89 & 4.5 & 22 & 0.9 & 24 & 111.7 & 22 & 8.6 & 24 & 0.002 & 0.022 & 48.1 \\
\hline 690 & 38.0 & 36.6 & 4.3 & 31 & 5.4 & 30 & 0.12 & 0.89 & 15.0 & 22 & 1.7 & 23 & 57.4 & 22 & 5.2 & 24 & 0.001 & 0.031 & 29.8 \\
\hline 709 & 39.5 & 28.1 & 23.4 & 29 & 9.0 & 30 & 0.12 & 0.90 & 4.4 & 20 & 1.7 & 23 & 105.4 & 22 & 11.5 & 24 & 0.005 & 0.011 & 53.1 \\
\hline 730 & 41.1 & 36.6 & 11.8 & 31 & 4.2 & 30 & 0.15 & 0.87 & 4.1 & 22 & 1.0 & 23 & 86.3 & 22 & 10.1 & 25 & 0.001 & 0.006 & 34.4 \\
\hline 749 & 42.6 & 48.3 & 4.4 & 29 & 2.2 & 29 & 0.47 & 0.63 & 2.7 & 22 & 1.0 & 23 & 35.9 & 22 & 12.6 & 24 & 0.002 & 0.038 & 56.3 \\
\hline 773 & 44.5 & 48.8 & 14.2 & 29 & 2.2 & 29 & 0.41 & 0.67 & 0.5 & 22 & 1.1 & 24 & 56.1 & 22 & 12.6 & 24 & 0.001 & 0.016 & 70.5 \\
\hline 789 & 45.7 & 45.8 & 3.5 & 29 & 4.9 & 29 & 0.22 & 0.82 & 1.6 & 22 & 1.1 & 23 & 46.7 & 22 & 8.8 & 24 & 0.000 & 0.027 & 55.7 \\
\hline 804 & 46.9 & 12.2 & 10.3 & 31 & 6.0 & 30 & 0.25 & 0.79 & 1.7 & 22 & 1.3 & 22 & 192.9 & 22 & 8.4 & 25 & 0.001 & 0.019 & 52.7 \\
\hline
\end{tabular}

Page $\mathbf{4 2}$ of $\mathbf{4 3}$ 
* Paq values < 0.1 = dominant terrestrial plant input, 0.1 - 0.4 = emergent macrophytes and, 0.4 - 1 = submerged macrophyte input (Ficken et al., 2000).

$4 \quad \mathrm{CPI}_{1}=\left[\Sigma\left(\mathrm{C}_{21}-\mathrm{C}_{29}\right)\right.$ odd $+\Sigma\left(\mathrm{C}_{23}-\mathrm{C}_{31}\right)$ odd $] / 2 \Sigma\left(\mathrm{C}_{22}-\mathrm{C}_{30}\right)$ even

$5 \quad \mathrm{CPI}_{2}=\left[\Sigma\left(\mathrm{C}_{20}-\mathrm{C}_{30}\right)\right.$ even $+\Sigma\left(\mathrm{C}_{22}-\mathrm{C}_{32}\right)$ even $] / 2 \Sigma\left(\mathrm{C}_{21}-\mathrm{C}_{31}\right)$ odd

$$
P_{a q}=\frac{C_{23}+C_{25}}{C_{23}+C_{25}+C_{29}+C_{31}}
$$$$
P_{\text {wax }}=\frac{C_{27}+C_{29}+C_{31}}{C_{23}+C_{25}+C_{27}+C_{29}+C_{31}}
$$

$7 \quad \mathrm{ACL}_{1}=(\Sigma[\mathrm{Ci}] \times \mathrm{i}) / \Sigma[\mathrm{Ci}]$, for $\mathrm{i}=\mathbf{2 3}-\mathbf{3 3}$ where $\mathrm{Ci}=$ concentration of $n$-alkane containing $\mathrm{i}$ carbon atoms

$8 \mathrm{ACL}_{2}=(\Sigma[\mathrm{Ci}] \mathrm{xi}) / \Sigma[\mathrm{Ci}]$, for $\mathrm{I}=\mathbf{2 2}-32$ where $\mathrm{Ci}=$ concentration of $n$-alkanoic acid or $n$-alkanol containing $\mathrm{i}$ carbon atoms 